\title{
A co-operative commonwealth in the Free State?
}

On 7 January 1922 Dáil Eireann narrowly accepted the Anglo-Irish Treaty that led to the establishment of the Irish Free State. ${ }^{1}$ During the contentious and bitter debates held in Dublin, former friends and allies disagreed over whether to accept or reject the Treaty. The co-operative movement's leaders emphatically supported those who urged its acceptance, which indicated a desire to secure a close accommodation with the incoming government. Æ urged the Irish people to support the Treaty or risk plunging Ireland back into 'scenes of bloodshed far beyond anything known for centuries'. He argued that acceptance of the controversial Treaty would bring Ireland closer to that 'solemn moment when full responsibility for our own civilisation and social order will be flung upon the shoulders of the Irish people. ${ }^{2}$ The new state, in turn, would have to recognise the co-operative movement's important efforts to bring the idea of the Irish nation into a practical reality. Looking forward $Æ$ asserted that:

The principles [the IAOS] has advocated have overflowed from the agricultural sphere into the national being ... we think the farmers who have enriched the movement by their varied application of the co-operative principle have reason to be proud of its effect on the thought of their country. ${ }^{3}$

That March, Horace Plunkett delivered a speech directed towards the incoming administration as much as the movement. He highlighted that as Irish people embarked upon the hard work of state building the IAOS already performed an immense amount of essential public work which no Government could undertake, but without which ... no Government could economically and efficiently develop agriculture'. Plunkett seized the opportunity to repeat his old mantra that any incoming Irish government needed to adopt the principle of 'better farming, better business, better living'. ${ }^{4}$ The IAOS looked to position co-operative societies at the centre of any plans for national development.

This chapter examines how co-operative expertise shaped an Irish plan for agricultural improvement and rural development. Little recognition of the influence that Irish co-operation held over an emergent independent political culture exists. Basil Chubb's influential work on Irish government identified 'the British influence 
[as] the most important in determining the pattern of much of Irish political thought and practice' and classified Irish agriculture as 'wholly geared to British needs. ${ }^{5}$ Garret Fitzgerald, Irish Taoiseach in the 1980s, articulated a similar view when he described the effect of British policy upon Irish development throughout the nineteenth and twentieth centuries as 'a form of exploitation of the Irish small farm structure ... an exploitation which had been carried forward into the first half of the post-independence period'. Not until Ireland became an enthusiastic supporter of the European Community in the 1970s did this dependency start to recede. ${ }^{6}$ The impact of nationalism, Catholicism and anti-intellectualism also counted as defining characteristics of government in Ireland. ${ }^{7}$ However, co-operative ideas, developed through systematic economic experimentation aligned to a network of societies, also defined Irish social and political life.

Co-operation shaped nationalist thinking as it provided an economic framework to imagine what an independent Irish state might achieve. The attainment of independence within the harsh political and economic realities of the 1920s saw the emergence of a style of pragmatic governance at odds with some of the utopian thinking that characterised nationalism. ${ }^{8}$ As argued elsewhere, from 1922 the Irish people 'became victims of their own aspirations' as post-independence governments failed to build the 'Gaelic Jerusalem'. ' This long anticlimactic epilogue to the independence struggle accords with Clifford Geertzs view that the aftermath of independence is often a deflating experience. ${ }^{10}$ Despite inauspicious beginnings, serious efforts to construct the Irish state did take place. This chapter begins with an outline of the postcolonial moment in Ireland in order to locate the co-operative movement against a backdrop of political, economic and military uncertainties that shaped public policy. Attention turns to examine how the movement played a central role in the creation and implementation of economic policy in the Free State. The chapter focuses on how the co-operative movement asserted itself in the southern jurisdiction. Partition of Ireland also saw a partition of the movement and the Ulster Agricultural Organisation Society (UAOS) represented the northern societies after 1922. However, the UAOS proved to be a less influential organisation in governmental terms, partly owing to the presence of a strong urban, industrial sector in Northern Ireland. Agriculture remained the main engine of economic development in the Free State, which provided greater scope for the IAOS to exert influence. The deliberations of the Commission on Agriculture are analysed to highlight how agricultural priorities for the new government emerged out of a two-year consultation between policymakers, economists and agricultural experts. The Commission's report, published in 1924, set out a governmental template with important implications for socio-economic development. The governmental strategies that arose from the final report show how co-operative ideas formed a key thread in the formulation of Irish rule as the movement once again acted as an instrument of the state in a way reminiscent of Plunkett's attempt to coordinate the IAOS and DATI. 
An examination of the work undertaken by co-operators at a national and local level helps to redefine a historical understanding of the state in Ireland. The historical anthropologist, Akhil Gupta, in his work on states and development, focuses upon how:

large-scale structures, epochal events, major policies, and 'important' people ... failed to illuminate the quotidian practices of bureaucrats that tell us about the effects of the state upon the everyday lives of rural people. ${ }^{11}$

Applying this insight to Ireland reveals how a popular understanding of the state formed at the point of the local co-operative society for rural inhabitants. Dairy farmers attended their creameries on a daily basis to supply milk and relied upon it as a source of income. The government created the Dairy Disposal Company (DDC) in 1927 as a means through which a congested creamery sector might be rationalised and reorganised. The establishment of this semi-state body helped to ensure the existence of the co-operative movement and establish it as the primary actor in the dairying industry. The decision to create the DDC also showed how the co-operative society formed the primary institution through which the future of agricultural policymaking was imagined in the early decades of independence. ${ }^{12}$ Another occurrence in the 1920 s was a revitalisation of cooperative credit societies which insulated farmers against the most destructive effects of economic depression. In the south-western dairying heartland credit societies helped farmers mitigate the worst effects of an epidemic outbreak that depleted cattle stocks. Many of the reforms that emanated from the Commission on Agriculture's Report provide evidence of a renegotiation of the relationship between the state and the IAOS. Applying Gupta's insight to post-independence rural Ireland shows that the state was constructed, and simultaneously revealed itself, at the site of the co-operative society. The frequent and mundane interactions that occurred at creameries and credit societies proved as relevant to the lives of many people as the debates about the controversial decision to adopt the Treaty.

The main analysis of the co-operative movement's part in the state-building process ends in 1932 with the electoral defeat of the first Cumann na nGaedheal government and an end to the Irish Free State's first decade of independence. The co-operative movement became an integral part of Irish political culture and an effective part of the state infrastructure throughout the first half of the twentieth century. More importantly the IAOS's modernisation project pursued since the late nineteenth century remained relevant in a context after independence. Cooperative organisations formed an important institution within the new state.

\section{The challenge of independence}

The IAOS approached the new phase in Irish political upheaval with pragmatism and abandoned any utopian pretensions as it stated, 'the co-operative 
commonwealth will remain a hope of the future rather than a gradually realised economic device or an immediately practicable ideal'. ${ }^{13}$ This sentiment summarised the movement's position after the War of Independence, but also reflected a general political moment in which the Irish Free State faced an array of challenges. Sinn Féin split into pro-Treaty and anti-Treaty factions, with the former rebranded as Cumann na nGaedheal in 1923 and which formed the first government of the Free State. ${ }^{14}$ A huge amount of activity characterised this government's decade in power as it sought to establish the parameters of sovereignty. ${ }^{15}$ Foreign policy emerged as an immediate priority as the Irish Government worked to renegotiate its relations with Britain and the Commonwealth in order to extend its autonomy, establish relations with other states and partake in the new forum for international relations, the League of Nations. ${ }^{16}$

The question of partition also preoccupied the Irish Government. At the end of 1920 the Government of Ireland Act established a six-county Northern Ireland. The establishment of a Boundary Commission as a concession offered to nationalists in the Anglo-Irish Treaty provided a possibility to renegotiate the border between Northern Ireland and the Irish Free State. A leak in the press about the Commission's work caused a public controversy and the Northern and Southern legislatures ratified the provisional border in $1925 .{ }^{17}$ On the home front, the government's objectives centred upon defence of the state from internal dissent, establishing a rule of law, trade policy, reducing national expenditure and developing agriculture. ${ }^{18}$ Despite a pessimistic economic and political context, the Irish Government benefited to a certain extent from one long-standing feature of Irish life - the resumption of systemic emigration after 1922 which decreased pressure upon resources. ${ }^{19}$

The IAOS looked to exert its influence over the area of agricultural development. In 1923, the organisation stated that Irish agriculture remained

one of the few stable elements in the changing world through which we have recently passed, and though its position to-day is crucial, no ultimate fears of its recovery can be entertained ... Co-operative principles and practice in relation to that industry are sound. ${ }^{20}$

The Irish Free State was an agricultural nation - a fact emphasised after partition with the retention of urban industries in Northern Ireland. Patrick Hogan, Minister for Agriculture, accentuated this point when he noted: 'national development in Ireland ... is synonymous with agricultural development'. ${ }^{21}$ The 1926 Census provided statistical support for such attitudes, showing that 53 per cent of the population engaged in agricultural occupations. By realising agriculture's untapped potential, no reason existed, 'why this country cannot in time have a largely increased population with an improved standard of living..$^{22}$ In 1924, agriculture, food and drink accounted for 98 per cent of national exports with 86 per cent of this output bound for the United Kingdom. ${ }^{23}$ The Free State remained integrated 
within the British economy where most of its agricultural exports ended up. By its long-term efforts to organise agriculture in Ireland the IAOS made a strong case for its relevance to Cumann na nGaedheal's plans. However, the utilisation of the co-operative movement might serve another government purpose. If the government used the IAOS to deliver rural policy, then the co-operative movement might achieve the dual objective of prioritising agriculture while limiting public expenditure.

The Irish Free State emerged onto the world stage in the middle of an agrarian depression. The Secretary of the Department of Agriculture and Technical Instruction (DATI) until 1921, T.P. Gill, summarised the fragility of Irish agriculture within the international trade structures after the First World War: '[ $\mathrm{t}$ ] he universal war has shaken and broken the economic fabric of the world, and, this being an era of interdependence, Irish agriculture is closely affected. ${ }^{24}$ The slump in prices that occurred in 1920-21 affected agriculture and left farmers exposed in a rural economy where sources of agricultural credit remained limited. Farmers found the 1920s a tough economic climate as the agricultural price index declined between 1920 and $1931 .^{25}$ Throughout the 1920s falling prices, depleted soil productivity caused by tillage without sufficient fertilisers during the war, crop and animal diseases, and poor harvests meant farmers faced economic hardship. ${ }^{26}$

As Minister of Agriculture, one of Patrick Hogan's priorities centred on the improvement of Ireland's export capabilities. Britain remained the primary buyer of agricultural goods and therefore Hogan wanted to ensure Ireland remained competitive in an overcrowded marketplace. ${ }^{27}$ According to the economist George O'Brien, a one-time employee of Horace Plunkett's, Hogan's policy 'did not involve any breach of continuity in the tradition of Irish farming. ${ }^{28}$ Hogan reinforced established patterns as he aimed to improve the quality of inputs (bulls, milk, etc.) and outputs (butter, eggs, bacon). ${ }^{29}$ Cormac Ó Gráda argues that from the 1920s 'the increasing role of governmental and government-supported agencies was probably a benign influence'. The Department of Agriculture (as the DATI was renamed in 1922) and IAOS produced statistical data that detailed economic activity throughout Ireland. These agencies encouraged an improvement in the quality of outputs and alerted farmers to new techniques. In short, investment made to these bodies 'was not money wasted in the pre-1925 period'. 30

Any debate about whether Irish national development pursued an agricultural or industrial policy immediately resolved in favour of the former. ${ }^{31}$ The next significant move made by the government was to decide upon a free trade policy as opposed to protectionism. Joseph Johnston, an agricultural economist involved with the co-operative movement at various stages of his career, wrote in favour of the pursuit of a free trade policy in January 1923 after an assessment of Ireland's 
economic capacity. The lack of viable industry meant Johnston believed that 'agriculture will remain our staple industry. It will remain the broad foundation on which all other industrial developments will be solidly and securely built.' For Johnston, the proper economic function of government lay in the creation of an improved transport infrastructure to help manage distribution costs, and interventions to raise the standard of education. He further argued that any proposed improvement relied upon the efforts of farmers themselves, both as individuals and through co-operation. ${ }^{32}$ The death of Arthur Griffith in August 1922 deprived the new administration of its first leader, but also the main champion of economic protectionism. The government's Fiscal Inquiry Committee recommended the continuation of a free trade policy and the Department of Finance supported these findings. ${ }^{33}$ Throughout the 1920s, the Irish economy remained 'an open one' attached to a free trade orthodoxy, which served the interests of agriculture. ${ }^{34}$

The partition of Ireland also affected the question of economic development and the co-operative movement's role in it. Northern Ireland contained the most industrialised section of the island, which allowed the Free State's policymakers to make the case for agricultural development as a natural way to maximise their national comparative advantage. After 1922, the Free State Government demanded that the IAOS divide itself into two separate organisations to reflect the new geo-political reality. Patrick Hogan advocated this change to prevent 'the effect of releasing, for expenditure in the Northern Area, money subscribed in the Southern Area. ${ }^{35}$ In Northern Ireland, James Gordon wrote to Captain Petherick at the Ministry of Finance to explain 'there is no doubt that co-operation is essential to combinations of farmers', but if the Northern Irish Government provided a direct grant to the IAOS that would raise 'a very serious question one which raises to mind a very serious political problem'. ${ }^{36}$ The two centres of co-operative activity belonged to the south-western and north-eastern regions where dairying formed a popular mode of farming and a frequent leakage of funding for co-operatives between the two jurisdictions appeared to be a likely occurrence.

On 31 August 1922, the IAOS formally divided into two organisations. The body responsible for co-operative development in Northern Ireland was reconstituted as the UAOS. ${ }^{37}$ With the loss of the north-eastern centre, the IAOS's numerical strength decreased. In 1922, the IAOS possessed 1,102 co-operative societies, but the loss of its north-eastern societies saw this figure drop to $608 .^{38}$ The IAOS accepted this economic rationalisation and the partition of the movement passed with little fanfare. The south-west emerged as a crucial region in plans for economic improvement as the engine of the Free State's butter production. Four-fifths of the total employment in dairying and bacon curing was concentrated in the south-western province of Munster. ${ }^{39}$ 


\section{The co-operative movement and civil war}

Military conflict provided a stern challenge for the Irish Free State Government in 1922. The capture of Dublin's Four Courts by Republican forces opposed to the Treaty in April 1922 challenged the legitimacy of the new state. The government responded in June by using the newly established National Army to crush the occupation. ${ }^{40}$ As a result, the Irish Civil War broke out in June and lasted until a ceasefire in May 1923. The Anglo-Irish Treaty was the nominal issue at stake, but Pro-Treatyites believed that irredentist republicans went further and called 'into question the proper basis of the social and political order in Irish society'. ${ }^{41}$ A vicious guerrilla warfare campaign took place between former comrades in the IRA and the most intense fighting occurred in counties Kerry, Cork and Limerick. ${ }^{42}$ The Civil War lasted for around a year but the legacy and memory of the war affected the political culture for decades. ${ }^{43}$ Conservative estimates on the loss of life place it at 800 National Army deaths, with almost certainly a higher figure for Republicans. No records exist for the numbers of civilian dead. ${ }^{44}$ The financial cost of civil war offered a major concern for a new administration intent on deficit reduction. Damage to infrastructure cost over $£ 30$ million with compensation and defence remaining high recipients of government expenditure. ${ }^{45}$

The Irish Civil War affected the co-operative movement on a national and local level. The most prominent individual affected was Horace Plunkett who was appointed to the Senate (the upper chamber of the new Irish parliament) by the President of the Executive and leader of the government, William Cosgrave. The honour recognised Plunkett's efforts in furthering the interests of Ireland throughout his career. Irish Republicans targeted the homes of these senators and in January 1923, Plunkett's home in Dublin was destroyed in an arson attack. Heartbroken, Plunkett departed for England that year and his influence in Irish affairs waned. Although he remained IAOS President until his death in 1932, his direct involvement in Irish co-operation ended. ${ }^{46}$

The Civil War also reduced Æ's interest in co-operative matters. Æ appealed to Irish Homestead readers to support the government in 'the conflict between Builders and Destroyers. ${ }^{47}$ In September 1923, the Irish Homestead became incorporated into the Irish Statesman, a journal intended to mark the intellectual foundation to the Free State. Æ continued as editor of the Statesman. Reportage on co-operation remained a feature, but the remit of the journal concentrated more upon political issues and became a rallying point for those who championed liberal causes such as opposition to censorship. ${ }^{48}$ Fr Finlay continued to serve on the IAOS executive and replaced Plunkett as the president. Robert Anderson provided continuity with the past and a source of leadership throughout this tumultuous period. ${ }^{49}$ However, the foundation of the new state coincided with a new generation of leaders that began to populate the co-operative leadership. When Anderson moved to lead the Irish Agricultural Wholesale Society in 1926, 
Dr Henry Kennedy replaced him as the IAOS Secretary and played a crucial role in the design of the DDC as a body to assist co-operative creameries. ${ }^{50}$

On a local level the civil war disrupted business. Co-operative societies strived for normality after recent attacks by Crown forces, but recovery was frustrated by the resumption of violence in $1922 .{ }^{51}$ Republicans destroyed trains and railway stations in an attempt to render government impossible. ${ }^{52}$ In Kerry, the Civil War took on a particularly brutal hue and events in the final months of the conflict created a resentment that survived long after the end of the conflict. ${ }^{53}$ Nicholas O'Brien's reports for the IAOS noted the negative effects of the civil war as the region's societies struggled to ship butter from Tralee, owing to the closure of the town's ferry service. Rattoo Co-operative Society shipped via a smaller harbour in Fenit instead, where it is very difficult and costly to get the butter on board and it is only through very hard work that it can be done owing to broken roads etc. ${ }^{54}$ Abbeydorney Co-operative Society also struggled to get butter to Fenit harbour due to broken roads. ${ }^{55}$ Societies also experienced an alarming drop in milk supply. At Newtownsandes Co-operative Society, the daily milk volume fell by 300 gallons, a fifth of the normal supply, 'owing to the cutting of the roads locally. ${ }^{56}$ Nevertheless, the infrastructure created by the co-operative movement remained largely intact and offered the Irish Government a means to attend to the needs of farmers.

The movement of the National Army through Kerry in late 1922 and 1923 disrupted business. On 26 November 1922, National Army troops occupied the creamery at Rathmore and erected a machine gun there. In December no members attended the society's Annual General Meeting 'owing to military operations in the district that day'. Organiser Nicholas O'Brien wrote to Anderson that the 'Committee have done everything to oblige the troops since their advent to Rathmore ${ }^{57}$ An attempt to hold the meeting on 19 December saw only seven out of 300 members attend. O'Brien concluded: 'it is quite possible that the poor attendance was due to a certain extent to the fact that sniping is an almost everyday occurrence in the village..$^{58}$

Personal antagonisms played out around co-operative societies as the Civil War continued. In January, the National Army held the manager of Rathmore Co-operative Society, Thomas de Lacy, prisoner on account of his son 'who is beyond my control being with the Irregulars..$^{59}$ De Lacy confided to Anderson that he and his family were under 'grave suspicion of helping the irregulars due to stories on the part of the people I am most anxious to clear out of Rathmore family + all'. ${ }^{60}$ Anderson responded without sympathy.

I am very much afraid that the fact that your son appears to be actively engaged with the Irregulars practically deprives us in the IAOS of doing what we would very much like to do for you. I think if your son take it upon himself to adopt such a course as he appears to have adopted, you are no longer morally or in any other way, bound to shield him. ${ }^{61}$ 
Such a sentiment reflected the temper of the times when a father might be asked to abdicate responsibility over the actions and politics of his son. Anderson supported the new government enthusiastically and wanted no impression that linked the movement to subversive activities to circulate. While Civil War politics destabilised social relations in rural communities for years afterwards, the leadership of the IAOS remained resolute in its support for the new state.

\section{Co-operativising the state: The Agricultural Commission and rural reform}

In his assessment of the first five years of independence Denis Gwynn argued that to 'anyone who has visualised the organisation, whether economic or social, of the Free State, it must be apparent that no Ministry in the Government of the country is of equal importance, in the ordinary life of the people, with the Ministry of Agriculture. ${ }^{62}$ During its first two years the Irish Government appointed a plethora of commissions to investigate a variety of issues that encompassed tax, financial policy, policing, communications and agriculture. ${ }^{63}$ The Agricultural Commission held the most significance for national development. The subsequent report was a sequel to a Commission of Inquiry into the dairy industry instigated by the revolutionary Dáil in 1920. That report, published in March 1922, established the 'cardinal principle that the first care of national production should be to supply and satisfy the Irish people at a remunerative price'. This belief proved to be 'especially true in regard to the production, or its manufacture into one or other of [the dairy industry's] various products' ${ }^{64}$

The Agricultural Commission included politicians from the Cumann na nGaedheal, Labour and Farmers' Parties, Department of Agriculture officials, and economists such as George O'Brien and Joseph Johnston. ${ }^{65}$ What remained of Sinn Féin still opposed the Treaty and therefore the party did not engage with the proceedings. The eventual report helped to establish the features of a new economic orthodoxy in Ireland. For George O'Brien, a professor of economics at University College Dublin, the Commission's proceedings revealed 'the general principles of agricultural policy in which I have continued to believe'. ${ }^{66}$ The Agricultural Commission met for the first time in November 1922 to investigate agricultural conditions and provide 'an assured basis for future expansion and prosperity'. It sat fifty-six times in public and thirty-eight times in private over the next eighteen months, and cross-examined 121 expert witnesses that included Robert Anderson and Father Finlay along with other representatives from the IAOS. ${ }^{67}$ Patrick Hogan received the Commission's Report in April 1924. The report provided the foundational text for agricultural policy going forwards and formed the basis for governmental thinking on rural matters for decades.

The Agricultural Commission and the policies it inspired show how a symbiotic relationship evolved between the co-operative movement and state throughout 
the 1920s. The Irish Homestead welcomed the decision to establish the Agricultural Commission, which $Æ$ hoped would range further in its deliberations than mere reconstruction and consider the grandiose task of 'building up a rural civilisation'. $Æ$ argued that the Commission should stimulate a conversation about what constituted the Irish mentality, which it described as 'virgin soil. Yet ... like all virgin soil, once it was cultivated it would be immensely productive.' Through this process of 'cultivation' $Æ$ believed the Agricultural Commission might provide a means by which 'we can begin to build up national life, trying to remedy defects and to burnish up our national virtues' ${ }^{68}$

Co-operators embraced the opportunity to deliver evidence to the Commission and sometimes the process revealed the political partisanship that coloured the thinking of activists. Such slips revealed aspects of an Irish mentality, but not as Æ envisaged. For example, the IAOS organiser, W.P. Clifford, argued that the co-operative movement looked 'to assert itself' in the new nation-state. Questioned by George O'Brien, Clifford exhibited the strident belief that political independence provided the necessary conditions for the promotion of organised co-operation within governmental structures:

O'Brien: What reason have you for assuming that the State will be favourable to the co-operative movement? ... It seems to me that you are delivering yourself into the hands of a powerful agency?

Clifford: The co-operative movement will be a popular agency. I am sure it will be able to assert itself.

O'B: Do you think that the co-operative movement in Ireland would have received better facilities for the last twenty years if the whole question of financing had been in the hands of the Department of Agriculture?

C: No, it was believed to be a Branch of the English Government in Ireland.

O'B: You think the millennium has come, and that the future Irish Government will do everything right?

C: I believe it is fair to infer that they will do a lot better than the British in the past. At least our experience so far has gone to prove that, disturbed as the state of the country has been.

Clifford expected political independence to instigate a change in the Department of Agriculture's attitude towards the IAOS. He equated the DATI with a 'Branch of English Government in Ireland', which reflected the attitude that developed towards that institution during the Great War. Clifford also betrayed a deep distrust of the civil service. When asked by O'Brien if he believed 'that the spots in the leopards in Merrion Street [where government buildings and civil service were based] will change?' Clifford responded, 'No, you will have to boil some of them. ${ }^{\text {'9 }}$ Clifford hoped political independence represented a millenarian moment whereby the sources of power in Ireland would be purged of British influence and lead to an attendant improvement to the co-operative movement's fortunes. 
The Agricultural Commission's Report established a blueprint for Ireland's long-term economic direction that incorporated the influence of a co-operative political economy. The report's introduction stated that:

Agriculture is the foundation on which the commercial and business life of the country is based, and the circumstances that affect agriculture react sensibly through the entire economic life of the nation. ${ }^{70}$

An agricultural depression combined with historical precedents to encourage a certain hard-headed approach to agricultural reform. 'Under such conditions,' the report continued, ' $a$ bad season may precipitate a famine. Ireland has had a bitter experience of this. Any closer [land] settlement policy must, therefore, be handled with great care, or it may produce calamitous results.' This signalled the emergence of a pragmatic attitude in which the smallholder no longer held a privileged position within governmental discourse. Instead the report iterated that 'large holdings ... afford a better standard of living to a smaller population'. ${ }^{71}$

Dissent from these conclusions was expressed. Thomas Johnson and Michael Duffy of the Labour Party submitted a Minority Report that differed from the central findings in important ways. Johnson and Duffy highlighted that population decline remained a problem and pointed out that Denmark and Holland, two countries with large agricultural sectors, did not experience similar demographic trends. While the Majority Report argued in favour of the need to deflate agricultural wages as a way to reduce farmers' costs, Johnson and Duffy condemned 'the error of treating every holder of agricultural land as an agriculturalist and the farming community as homogenous'. The main report overlooked small farmers and labourers in favour of 'the large farmer who depends wholly on wage labour and sells his produce for export'. The Minority Report recommended that the government should impose a limit to the maximum size of holding any farmer could own to increase the number of people who worked on the land. ${ }^{72}$ The government ignored this advice.

Agricultural production and marketing deserved the main share of allocated funding, while improvement relied upon 'a better understanding both of the theory and practice of farming'. The Commission concluded that:

We firmly believe in the co-operative system, as calculated to promote better business methods, and, we consider that the state may, with advantage spend substantial sums in the teaching of practical co-operation. ${ }^{73}$ (Emphasis added)

The utilisation of co-operative principles to overcome economic challenges in agriculture established continuity with the Dáil's utilisation of co-operative principles to experiment with areas such as banking and land purchase during 1919-21. The report promised to synchronise the relationship between the government and co-operative movement. The Commission outlined a limited role for the state with co-operative societies envisaged as the agents through 
which the practical work of agricultural development would be carried out. While the government might achieve a certain amount through funding and provision of education, 'agricultural recuperation must rest with the individual farmer, whether working singly or organized in co-operation with his fellows. ${ }^{74}$

The Agricultural Commission aimed to create an Ireland imbued with the principle of 'self-help through mutual help' and stressed the importance upon 'the immense advantages of unrestrained [v] oluntary effort. ${ }^{75}$ The state's role was to provide a context that allowed co-operation to flourish and enabled the population to instigate their own improvements to their industry. This held the benefit of economy in a time of austere financial planning as the government utilised a network of expertise already in operation. The Commission highlighted key areas for rural reform that occupied experts throughout the 1920s and the level of success achieved in each area carried long-term implications for economic development. The Agricultural Commission identified co-operation as the most effective tool to improve farmers, but believed that 'co-operation is imperfectly understood and practised in the country. ${ }^{76}$ The main proposals included the reorganisation of the co-operative movement, the standardisation of co-operative marketing and an attempt to re-stimulate co-operative credit provision.

\section{Reorganisation of the co-operative movement}

As the Agricultural Commission identified dairying as 'the foundation on which the whole structure of our agricultural economy depends', ${ }^{77}$ an invigorated agricultural sector required a good working relationship between the government and IAOS. The failure to turn the general purpose societies into the flagship business of the movement meant that the IAOS concentrated once again on creameries. In evidence given to the Agricultural Commission in 1923, Robert Anderson highlighted that any gains in the distribution side of co-operation 'are always in connection with some other activity either a Creamery or a poultry co-operative effort. The co-operative stores [are] ... not a conspicuous success anywhere. ${ }^{78}$ Whatever progress co-operation made in new directions in previous years, by the 1920s any expansion of the movement remained associated with the creamery business. This suited the government's aims as dairying could play an important role in strengthening Irish agricultural productivity and directly contributed to Ireland's export trade in livestock. ${ }^{79}$ Dairying encouraged a mixedfarm economy and led to greater diversity of agricultural outputs. ${ }^{80}$ Dairy farmers used land more intensively than graziers who farmed to fatten cattle for sale as beef exports. Dairying incentivised a higher density of cattle per acre and these farmers tended to own pigs, calves and poultry. ${ }^{81}$

Working through the IAOS proved to be an attractive course of action for the Department of Agriculture. In 1922, the government approved a state grant for the IAOS to replace the Development Commissioner's funding which 'contributed in no small degree to the success of the co-operative movement in 
Ireland' ${ }^{82}$ From the point of view of co-operators this decision vindicated the independence process and their support for the new administration. The finds guaranteed the long-term future of the IAOS and served as an endorsement of the movement by the Irish Government. However, the grant came with new conditions that paved way for greater government interference.

The right co-operative spirit implies a new outlook in both business and social life and this change of mind can only be reached through slow and patient steps ... It has not been our duty to inquire into the domestic arrangements and inner working of this society [IAOS], but we recommend the government to make such enquiry before it finally decides on the amount and conditions of any state grant. ${ }^{83}$

An annual renewal of the state subsidy provided the government with an opportunity to re-make the IAOS and integrate it within the workings of the state. The reduction of the national debt remained the guiding financial principle of the 1920s. However, the Minister of Finance, Ernest Blythe, proved willing to deviate from this position to protect vital sections of the Irish economy. Blythe's budget statements earmarked special sums of capital for the co-operative movement under the categorisation of 'abnormal expenditure’. In 1927, Blythe spent $£ 85,000$ in special loans for co-operative creameries, which accounted for more than half of the abnormal expenditure granted to the Department of Agriculture. ${ }^{84}$

The IAOS worked to overhaul its creamery network and an expanding workload throughout the 1920s placed pressure upon its 'administrative, organising and inspectorial work'. This led to a temporary abandonment of publishing annual reports between 1924 and $1930 .{ }^{85}$ During these years the government and IAOS collaborated to rationalise the creamery movement in Ireland. The Department of Agriculture surveyed the machinery of the IAOS in 1926 and proposed that:

Meetings of the Committee of the IAOS should be attended by a representative of the Minister who will keep him informed of their proceedings and convey to them such information and advice as he may deem helpful for their guidance. ${ }^{86}$

The IAOS assented to these proposed changes, which included a restructured Executive Committee to incorporate six representatives of the Minister of Agriculture. ${ }^{87}$ These representatives reported to Hogan on the subject matter discussed at IAOS meetings and provided detailed feedback on annual expenditure and the decisions taken by the Committee. ${ }^{88}$ This provided the Department with significant influence over the IAOS and ensured the co-operative movement remained transparent for governmental purposes.

Government oversight of the co-operative movement went beyond IAOS reorganisation. In 1924 the Dairy Produce Act brought creameries under tighter regulation that policed hygiene, cleanliness, and inspected the quality of all butter produced. The legislation required all creameries and dairy produce exporters to register with the Department of Agriculture. The Act empowered inspectors to 
'enter any premises upon which dairy produce is manufactured ... [to] inspect all plant, machinery, appliances, and utensils used in such manufacture'. While creamery inspections had previously occurred under the DATI, the Dairy Produce Act granted the state greater powers of intervention and laid greater responsibility with the individual society. Registered premises remained open to inspection with all produce subject to surprise tests and failure to comply led to prosecution and a revocation of their licence. The legislation also demanded that all premises maintained a high standard of cleanliness and hygiene, and policed the outward presentation of creamery employees. Meanwhile, creamery inspectors regulated butter quality and capped the acceptable level of moisture at 16 per cent. ${ }^{89}$

This new inspectorate performed similar functions to those carried out by IAOS organisers in previous years. Departmental inspectors visited certain premises more than once a month. These inspections focused upon issues such as ventilation, lighting of premises, cleanliness of staff and quality of butter. ${ }^{90}$ The Department of Agriculture looked to standardise all creamery premises, which required the extensive reconstruction of some societies. However, the new inspectors created new workloads for IAOS around the maintenance and hygiene of their creameries. For example, following an inspection of the creamery at Rathmore, the Department ordered management to install modern machinery, which included vats for milk storage, refrigeration technology, hot water tanks, and arrange the erection of cold storage rooms. Creamery managers then passed these orders on to IAOS engineers whose expertise they remained reliant upon. ${ }^{91}$ The manager of Rathmore Co-operative Society wrote to James Fant a month after the Department ordered the creamery to improve:

the Dept are urging pretty hard the carrying out of their recommendations + I hope you will not take me as pressing unduly on you to kindly have specifications sent out at earliest convenient date. ${ }^{92}$

The Department of Agriculture placed pressure on co-operative societies to meet expected high standards through follow-up visits. The effect of these inspections raised the standard of milk supplied by farmers because the departmental inspector relieved 'the manager of the unpleasant duty of rejecting milk which is impure or stale' ${ }^{93}$ The Department of Agriculture built up a detailed understanding of dairying in this way.

In 1925, the new dairy inspectors gathered to discuss the application of the Dairy Produce Act. Assembled delegates debated where improvements on the Act should be targeted, but argued that any reform required the support of the IAOS to effect a serious change in this direction. Topics ranged from how to deal with suppliers of unhygienic milk to the possibility that dairy inspectors might co-opt the police force to monitor creameries. However, the most urgent topic that received their consideration related to the diffusion of creameries. Within a year, dairy inspectors concluded that in some districts there were far 
too many small creameries, several of which were running at a loss'. The inspectors proposed an amalgamation of many of these societies, but felt the Department of Agriculture 'could not usefully intervene'. Instead, they asserted that 'the Irish Agricultural Organisation Society would perhaps be in a better position to deal with matters of this kind'. ${ }^{4}$

The government instigated two important reforms to this end. These were the creation of the government-backed DDC in 1927, followed by the 1928 Creamery Act. Taken together these actions effectively granted the co-operative movement a state-sponsored monopoly over dairying, creating a policy intervention designed to deal with the problem of over-concentration of creameries in certain parts of the country. The IAOS and the Department of Agriculture agreed that more creameries were operating in the dairy heartlands than the available milk supply justified. A concentration of co-operative and private creameries in Ireland's south-western dairying districts created an inefficient system, with two types of firm competing for the same supplies. Furthermore, fierce competition to win the dairy pastures of the south-west provided no incentive to stimulate dairy farming in other regions. ${ }^{95}$ In 1907, Father Finlay conceded that in the movement's formative years the number of creameries grew too rapidly. Finlay advocated a smaller number of creameries, rather than the large amount in whose members the spirit of co-operation was defective'. ${ }^{96}$ However, overwhelming desire to oust private competitors meant the IAOS acquiesced in the unchecked growth and Finlay's advice on this issue remained unheeded.

The debate about a more streamlined co-operative movement emerged again during the Agricultural Commission. Denis Hegarty, secretary of the Irish Creamery Manager's Association (ICMA), argued that the quality of Irish butter had declined during the First World War - something he had witnessed as a wartime member of the Butter Export Committee. The resurgence of international competition after the war concerned Hegarty and he identified the major weakness of Irish dairying in the fact that 'the creameries in the best districts in Ireland are in very many cases too numerous, which means severe competition for milk, leading to many abuses'. Co-operative creamery managers accepted milk of dubious quality to secure the custom of suppliers away from local competitors. Hegarty highlighted that Danish creameries suffered from no such impediment, which meant 'the Danish Dairy Manager is only concerned with turning out butter of the highest quality. ${ }^{97}$ The legal precedent established by the McEllistrim $\mathrm{v}$ Ballymacelligott judgment proscribed co-operatives from compelling members to supply milk to one creamery. Furthermore, lower standards in Irish butter production stemmed from the presence of 'creameries at every cross roads' ${ }^{98}$ Two or three creameries operated in a district where one would have sufficed and the Agricultural Commission's final report found 'that steps should be taken to wind up all such non-effective societies' ${ }^{99}$ 
The long-standing bitter rivalry that existed between co-operative and private creameries reached a fierce pitch during this period. In 1924, 580 creameries operated in the Free State, with 180 of these classified as proprietary concerns. Although co-operative creameries outnumbered private ones, in reality many struggled to compete with 'the financial resources of proprietary vested interests'. ${ }^{100}$ County Kerry represented one of the regions where the dairy industry operated in a somewhat dysfunctional manner. The county housed 57 creameries and constituted a hotly contested battleground for milk supplies. ${ }^{101}$ For example, the troubled Rathmore Co-operative Society tried to compete with a local creamery operated by Lakelands Dairying Company. Rathmore's manager complained to Robert Anderson that Lakelands sold low-quality, blended butter and marketed this product as high-quality creamery produce. He advised Anderson to have the matter investigated as Irish Creamery Butter has been tampered with too often + too long and it is now a national + not a local question'. Anderson informed the Department of Agriculture of these practices utilised by private creameries. ${ }^{102}$ In July 1924, James Fant warned the IAOS, 'this Society [Rathmore] will need very careful watching otherwise the local prop. Creamery will wipe it out'. ${ }^{103}$ However, the co-operative movement possessed one distinct advantage. The private sector lacked a coherent agency akin to the IAOS as each company pursued its own interests.

In 1926, the largest creamery proprietor, the Condensed Milk Company of Ireland (CMC), hovered on the brink of collapse as a result of competition with co-operatives. The CMC owned 113 creameries and the loss of these threatened to upset dairy production. ${ }^{104}$ In November 1926, the CMC approached Henry Kennedy with a suggestion for the IAOS to purchase their creameries. The IAOS lacked the required funds to carry out such an ambitious transaction and Kennedy passed on the offer to Patrick Hogan to consider a state purchase of the private sector. In January 1927 the government agreed to the purchase of the largest proprietary concern as an important step in the reorganisation of the creamery sector. ${ }^{105}$ Against a backdrop of falling agricultural prices this decision set an important industrial precedent as other creamery owners filed for bankruptcy and petitioned the government to buy out their premises.

Other proprietors attempted to offload creameries at as high a price as possible to their co-operative competitors but societies proved unable to pay the requested prices. Thomas de Lacy, the manager of Rathmore Co-operative Society, expressed disgust at the prices sought by private creamery owners in County Kerry. De Lacy equated these owners with the traditional enemy of farmers: 'Most undoubtedly', he wrote to Kennedy, 'Creamery Proprietors are a worse form of Landlordism than that of the Landlords.' A meeting of co-operative societies in Kerry passed a resolution that urged the county's politicians 'of all shades of politics' to persuade farmers who supplied private creameries to direct their milk to co-operatives. 
According to de Lacy, 'I see no other way to get the Creameries under the control of the farmers \& I believe no matter how long the business may hang fire Compulsion will have to come.' ${ }^{\text {106 }}$

Compulsion grew out of necessity in the end. The government recognised the collapse of private dairying as an opportunity 'to arrange for the purchase of the interests controlling a considerable number of such [surplus] creameries' ${ }^{107}$ The first state-sponsored agency, the DDC, was established in 1927 to carry out such work. The DDC acted as a clearing house that administered the businesses until either a local co-operative took them over or absorbed the milk suppliers. Where a creamery proved unnecessary due to congestion, the DDC closed it down. Most of the creameries purchased by the DDC were located in Cork and Kerry, which led to the near extinction of the private creamery sector in those counties. ${ }^{108}$ The government's actions consolidated the position of the IAOS and allowed their creameries to concentrate upon matters related to quality improvement and policing suppliers.

The government built upon the DDC's establishment with the introduction of the Creamery Act in 1928. This legislation tightened regulations around creamery operations and pursued reorganisation through restrictive regulations around the establishment of new creameries. The establishment of any new creamery required the permission of the Minister of Agriculture from this point onward. ${ }^{109}$ The Act also locked in suppliers to their local co-operative creamery, and stated that if a society issued shares to a milk supplier "it shall not be lawful without the consent of the Department signified in writing for any other society to take any supply of milk from such person'. ${ }^{110}$ This tied Irish milk suppliers to a co-operative creamery in a similar fashion to the Danish model and effectively overturned the House of Lords' verdict on McEllistrim $\mathrm{v}$ Ballymacelligott to proscribe the locked-in relationship. The Act also prevented the establishment of co-operative societies in districts with little milk supply. The Creamery Act showed the willingness of the Irish Government to intervene in agricultural matters and shored up the position of the co-operative movement within the dairy industry.

Reorganisation expanded the frontiers for co-operative dairying as the process encouraged the spread of creameries into new regions. Creameries were introduced into the great midlands plain - a region long associated with grazier farming rather than dairying. ${ }^{111}$ New creameries, such as Donaghmore Co-operative Society in County Laois, grew into long-standing fixtures of the local economy. ${ }^{112}$ By 1929, forty-six new creameries had been established which included some 'built in districts where creameries did not exist before'. Experienced co-operators sometimes migrated to these areas and brought with them the expertise acquired over years. The Irish Times reported how some of these creameries were started by 'a colony of progressive emigrants' from County Kerry. 'These people brought with them the dairy farming tradition' and cattle which 'were already known as good milkers'. This diffusion of the creamery system into new territory represented 
'the efforts of the Department of Agriculture and the Irish Agricultural Organisation Society in regard to the development of the Irish butter industry on a sound basis, so as to enable it to hold a foremost position on the markets of the world'. ${ }^{113}$

By 1931, the DDC had purchased 170 private creameries. This effectively ended private-sector involvement in Irish butter production. Of these, 44 creameries converted into co-operatives, 79 closed down permanently and 47 remained under the direct control of the DDC. The DDC absorbed 17 co-operative creameries during the same period. The IAOS organisers negotiated the transfer of former proprietary creamery suppliers to the nearest co-operative creamery, as well as the conversion of DDC-administered creameries into co-operative societies when required. ${ }^{114}$ The state-sponsored body emerged as an ad hoc solution to the problem of reorganisation, but became a long-term one instead. The DDC ensured that the co-operative movement remained the dominant force in Irish dairying.

Reorganisation occurred at an opportune moment as the Wall Street Crash in 1929 presaged another period of great uncertainty within the industry. However, without government support throughout the previous decade, the consequences might have been more devastating. As it was, co-operative creameries survived the Great Depression and remained important sites around which developmental policies were conceived and carried out. The Agricultural Commission had emphasised the need for the reorganisation of the co-operative movement. While the impetus for this reform came from the government, the IAOS organising staff helped facilitate the successful application of these reforms. More importantly, the policies normalised the co-operative as the archetypal dairying business for much of the twentieth century. Independence brought about a new approach that saw a return to, and increased collaboration between, policymakers and co-operative experts.

\section{Co-operative marketing and improvement of agricultural produce}

Besides the root-and-branch reform of the dairy industry pursued by reorganisation, a drive to improve the reputation of Irish dairying also formed a key strand of the Agricultural Commission's deliberations. In the post-war period, Irish farmers proved slow to adopt new marketing techniques or respond to consumer feedback with the result that Irish butter carried a mixed reputation on the British market. Cormac Ó Gráda concludes that Irish farmers 'responded lackadaisically to the opportunities presented by the First World War'. ${ }^{115}$ By the 1920s, any short-term gains won during the war dissipated. That decade saw a resumption of international competition between dairy producers as Irish farmers competed with new competitors. The introduction of refrigeration in the 1920s allowed New Zealand farmers to supply butter, meat and cheese to the British market. ${ }^{116}$ A substantial problem for Irish butter producers related to the failure of creameries to co-ordinate their marketing. All creameries, including co-operatives, marketed their produce as 
individual concerns. Butter quality varied from one creamery to another, which harmed the reputation of all exports. At the same time, international competition grew ever more aggressive. In 1915, the Danes supplied over 102,000 tons of butter to Britain, but this dropped to 14,200 by 1918 . By 1923, Danish farmers reasserted their dominance of the British market as they supplied 110,521 tons of butter. ${ }^{117}$ Moreover, new competitors made the British marketplace a congested field for dairy farmers. ${ }^{118}$

The Agricultural Commission identified 'the present system of marketing farm produce ... [as] wasteful and uneconomic'. ${ }^{119}$ A policy priority then existed around the need to raise the international profile of Irish dairy produce. Evidence from the continent showed that co-operative marketing raised the small farmer's productivity most effectively. ${ }^{120}$ The co-operative movement emerged as the most likely instrument around which to build a new marketing approach. As such, the Agricultural Commission looked to the IAOS to organise marketing of creamery produce and argued that if farmers were to combine to sell their produce in larger quantities than at present, many of the economies inherent in large scale transactions could be effected'. Any effort towards this end 'must be the result of the farmer's co-operative and other organizations'. The Department of Agriculture envisaged its role as one that provided technical support and the report concluded, 'what is contemplated in this connection is a large scale development of co-operative marketing. ${ }^{121}$

The IAOS long regarded the failure to unite co-operative farmers behind a single, recognisable brand as a major shortcoming to its work. Previous attempts to standardise co-operative creamery produce failed. In 1910, the IAOS launched its Co-operative Creamery Butter Control Scheme. The voluntary subscription of individual societies to the scheme enabled the IAOS to contract a dairy bacteriologist to monitor the butter made at each creamery. When the bacteriologist approved the quality of this butter, the society received the Control Mark which conveyed a standard of excellence to the consumer. ${ }^{122}$ However, the majority of co-operative societies never embraced the scheme. Within four years, the IAOS Committee was lamenting the disappointing support and pronounced that "with the exception of less than half a dozen creameries ... [the Control Scheme] has almost become a dead letter'. ${ }^{123}$

The Agricultural Commission received various recommendations about how to establish a national brand. The ICMA believed that Irish butter's improvement required a national grading system, but felt this should only be carried out on a voluntary basis. ${ }^{124}$ W.P. Clifford argued that a degree of compulsion was necessary. Clifford believed that the creation of a national brand offered an important method to improve butter's quality and reputation, but for this to occur, 'every Irish creamery should be open to inspection and should be compelled to send samples regularly and frequently to surprise butter inspections ... linked up with bacteriological examination and research'. ${ }^{125}$ The Dairy Produce Act partially 
resolved these concerns, but the precise mechanism of any marketing scheme required definition. A scheme co-ordinated by the IAOS offered a realistic possibility for success. Support for co-operative marketing transcended some political divisions as the Labour Party's Thomas Johnson and Michael Duffy stressed 'the necessity of [the marketing brand] being on a large scale'. ${ }^{126}$ The co-operative movement represented the agent capable of rolling out an effective scheme, as it alone possessed the necessary reach and scale.

The IAOS launched its Butter Control Scheme in 1924 but to a largely indifferent movement. The manager of Rattoo Co-operative Society responded to an IAOS appeal with a pessimistic assessment of his committee's enthusiasm for the scheme. William O'Connell wrote to Robert Anderson informing him that the matter would be placed before the committee at the next meeting, but 'if participation in the scheme entails any expense in the way of further subscription this Society will not join'. ${ }^{127}$ The pressure on societies' financial resources meant that the effort to ignite interest in the Butter Control Scheme failed.

The objective set out by the Dairy Produce Act to level up the quality of Irish produce remained unfulfilled. The next attempt to create a co-operative marketing scheme occurred in 1927 and coincided with the retreat of the private creamery sector. The decline of proprietary creameries meant farmers could no longer play two creameries off against each other and this promised to lead to a substantial improvement in creamery output. However, 'the long years' of creameries selling butter 'failed to secure anything more than spasmodic recognition for the general excellence of [Irish] butter'. The IAOS launched a new central marketing organisation in collaboration with the ICMA called the Irish Associated Creameries (IAC). Denis Hegarty served as the IAC's secretary alongside a board of directors drawn almost entirely from the co-operative creameries. As the creamery industry possessed a 'co-operative character and organization' it presented the first field of economic activity suitable for federated marketing. The IAC aimed to revolutionise the unsatisfactory position Irish dairy farmers found themselves in, 'by eliminating inter-competition in sale within our own fold, and by eliminating indifferent selling' ${ }^{128}$

The IAC requested that co-operative societies subscribe and promise to distribute all produce through its auspices for a period of three years. The IAC employed marketing agents based in Britain who opened up new relations with buyers previously not contacted and ensured a wider distribution of Irish butter there. In return, the societies received a guaranteed fixed price for their produce. The IAC marketing scheme recorded impressive initial results. Throughout its first year, IAOS organisers tried to convince co-operative committees of the benefit attached to IAC membership. Societies who resisted previous efforts to federate in other organisations came in. Charles Riddall, promoted to the position of IAOS Assistant Secretary, wrote to Denis Hegarty to inform him that Rattoo Co-operative Society's decision to affiliate with the IAC 'would not have been 
made but for the attendance of our Organiser, Mr O’Brien'. ${ }^{129}$ Rattoo Co-operative Society's affiliation to the IAC signalled a renewed enthusiasm for an active role in the national movement it had lacked in previous years. The relationships between IAOS employees and individual societies formed a key component to any success enjoyed by the IAC. In Rathmore, where the co-operative society still hoped to rebuild a creamery business in terminal decline, Thomas de Lacy informed Henry Kennedy that he 'had no difficulty in getting the [committee] meeting to consent to become members of the IAC'. ${ }^{130}$

Within one year 80 per cent of all co-operative creameries had subscribed to the IAC. The level of subscriptions suggested that individual societies viewed themselves as part of a national federation of co-operatives. The Department of Agriculture hoped that this uptake would lead to 'more economic marketing due to reduction in freight charges and cost of handling and the elimination of injurious competition between creamery and creamery on the British market'. ${ }^{131}$ Although 80 per cent uptake represented a success of sorts, crucially one-fifth of all co-operatives did not subscribe to the IAC. ${ }^{132}$ The IAC expressed dismay at the failure of sections of the creamery sector to affiliate. At the end of its first year, the IAC's board hoped that 'a juncture has been reached in the development of co-operative selling ... when such an attitude towards the duties of citizenship ... does not meet with the approval of the great majority of Dairy Farmers' ${ }^{133}$

Co-operative creameries unaffiliated to the IAC traded without the restriction of a set maximum price. Enthusiasm for the scheme declined as a result. A year after joining the IAC, the manager of Rattoo Co-operative Society requested Henry Kennedy to send an organiser. Nicholas O'Brien arrived to find an unsettled committee who pointed out that 'creameries outside the Scheme were getting at least $8 /$ - per cwt. nett more for their butters' ${ }^{134}$ O'Brien discovered ebbing support for the marketing scheme. The presence of only one nearby creamery operating outside the IAC's constraints undermined the commitment of those who already agreed to participate. Neighbouring Lixnaw Co-operative Society refused to affiliate, which created a source of local tension and encouraged hostility among Rattoo's milk suppliers towards the IAC. The committee at Rattoo directed the creamery manager to break the IAC contract and sell the society's produce elsewhere. Furthermore, the committee stated that if the IAC intervened, the 'Society will attack the IAC in the press with a view to bringing about its liquidation'. 135

The breakdown in goodwill caused by a lack of support from all co-operative societies defeated efforts to make the IAC a success. Nicholas O'Brien observed wide disapproval towards the IAC among farmers in north Kerry. At Abbeydorney Co-operative Society, O'Brien noted that the attempt to frame co-operative marketing as a national issue backfired as committee members felt this undermined their local authority. Rather than strengthen the relationship between local and 
national organisations the IAC placed a strain on that relationship and alienated individual societies from the co-operative movement's national leadership. O'Brien filed his views on the subject in a report to Dublin:

The most serious thing about our work at present is the wave of discontent of which you speak and, of course, it follows that discontent with the IAC means diminished confidence in the IAOS. However, I am an optimist and we will weather the present squall. The IAC will set itself right. ${ }^{136}$

O'Brien's optimism proved misplaced.

The rejection of the brand by a sizeable minority of co-operative societies revealed how local factors limited the extent to which the co-operative movement could implement the Agricultural Commission's recommendations on centralised marketing. The fact that 20 per cent of co-operative creameries refused to subscribe to the IAC undermined the effort to create a unified national brand and the purchaser of Irish butter remained 'well positioned to exploit the different creameries pricewise'. ${ }^{137}$ The IAC did manage some successes on behalf of their members as it reduced the price differences between Irish butter and its competitors. IAC staff worked with potential customers on behalf of dairy farmers 'to re-establish confidence on the part of the buyers' and they managed to 'regain lost connections and consolidate existing ones'. Creameries played a greater role in the regulation of their own industry as the co-ordinated sales of butter that went through a quality-grading process, which strengthened their position to negotiate a fairer price. However, the fact that 'some of the outside creameries have done better than those inside' caused divisions within the co-operative movement. ${ }^{138}$ The short-term perspective of those creameries that sat outside the scheme, and who indirectly benefited from the IAC's efforts, meant that a return to the system of individual marketing proved inevitable.

In 1930 and with the onset of global depression the IAC ceased trading as the attempt to create a national brand ended in failure. The collapse of the IAC highlighted the limitations of co-operative behaviour in practice. Its abandonment proved short-sighted as the Great Depression caused by the Wall Street Crash created unfavourable economic circumstances for agricultural producers. Although Irish farmers voluntarily associated around their local co-operative, the sense that they belonged to a national movement possessed limitations. In New Zealand, a similar marketing scheme saw complete uptake by dairy farmers. Every butter producer received 8-10 shillings more per cwt. even though the product was inferior to Irish butter. ${ }^{139}$ Irish farmers proved more concerned with competition from several miles away than competitors from Denmark or New Zealand. The elimination of the threat from private creameries by the mid-1920s only amplified this tendency. In short, co-operatives struggled to co-operate with other co-operatives. 


\section{Co-operative credit}

The 1920s saw a renewed impetus to create a vibrant co-operative credit. The IAOS's failure to build an effective co-operative credit movement in previous years proved imprudent as farmers experienced a squeeze on living standards. Although, in 1924, the farmer received on average ' 40 per cent more for his produce' compared to 1914, 'his cost of living has risen 80 per cent and the expenses and requirements of his trade have risen, in some cases, over 100 per cent' ${ }^{140}$ The Agricultural Commission presented policymakers with an opportunity to reintroduce the provision of co-operative credit as an important source of rural credit. The IAOS Annual Report for 1922 found that many of its existing credit societies maintained 'a moribund existence'. At the same time, the IAOS acknowledged that co-operative banks provided an invaluable service to a district by 'utilising the small deposits (which otherwise go out of the district if not out of the country) to irrigate and fertilise the parish through the local society'. ${ }^{141}$ The neglect of agricultural credit by the IAOS represented a major failure to nurture a more co-operative economy.

H.F. Norman, Assistant Secretary of the IAOS, submitted evidence to the Agricultural Commission on the historical importance of co-operative credit to rural society. The emergence of local co-operative banks in the late 1890s sprang from the fact that "joint stock banks did not lend as freely to the smaller type of farmer. I do not think that they still lend money to the very small farmer unless he has very sufficient security.' Norman argued that credit societies educated farmers to behave with greater financial responsibility. In considering loan applications, a credit society's committee paused to 'consider the economic character of the borrower. They must also consider if he is a good mark for the money, his general character for thrift as well as other matters, all these things have to be taken into account.' Farmers who used co-operative credit societies, 'began to be thrifty' as 'they began to add to their stock and laid the foundations of modest prosperity'. Thrifty farmers then 'from having been previously men that were pulling the devil by the tail [...] became fairly prosperous' ${ }^{142}$

The primary purpose of co-operative credit societies was conceived as an educational one and rulebooks for these societies were started: 'The objects of an Agricultural Bank are to assist its members with capital, to educate them in the true uses of credit, and to foster the spirit of mutual help or co-operation. ${ }^{143}$ Co-operative credit societies bound members together through a shared economic interest. They provided a forum in which local members drawn from one area influenced one another's financial position. Co-operative credit societies encouraged financial mutuality. Unlike loans offered by the joint-stock bank or shopkeepers, co-operative credit societies drew upon 'the expert knowledge of the community' and placed this 'at the service of the man who gets the loan'. The process of loan applications opened up the business of individual farmers to the scrutiny of their peers. Credit society committees granted loans 'for a purpose likely to effect 
economy'. Norman explained that he heard of 'many cases in which the borrower thinking he would take a loan for one particular purpose, has been induced to take it up for another purpose which in the studied opinion of the committee was more likely to pay him'..$^{144}$

An ideal type of farmer for the post-independence era can be ascertained from Norman's evidence. Norman stressed that when one considered the position of 'the large farmer ... you are dealing with men with some education'. The role of the co-operative society held a different role for these subjects. Norman emphasised that the importance of co-operative credit societies lay in the aid they offered to 'the small farmer who live mainly in backward districts ... [where] the habit of having the purpose of the loan criticised leads to the development of a proper sense of credit amongst borrowers'. ${ }^{145}$ Small farmers, long the target of improvement, remained defined by their backwardness. In contrast, the larger farmer, with access to greater agricultural resources, embodied the characteristics of an educated, modern rural subject. While Norman spoke about past efforts to provide assistance through co-operation for smaller farmers, he emphasised an idea that gained currency after independence. Larger farmers personified the desirable characteristics spoken about by agrarian experts.

The small farmer's position as an idealised subject within co-operative discourse declined after independence. In 1904 Plunkett praised the farmers' adoption of co-operative organisation as something that worked in the interests of all farmers, smallholders and large farmers alike. This mutual regard was central to the success of the movement in its earlier years and without this 'vein of altruism, the "strong" farmers would have held aloof and the small men would have been discouraged by the abstention of the better-off and presumably more enlightened of their class'. ${ }^{146}$ By 1922, attitudes towards the small farmer among co-operative leaders shifted. Fr Finlay told the Agricultural Commission that the IAOS still aimed 'to raise the economical position of the small farmer and moderately sized farmer to a level of economic culture with the large farmer. ${ }^{147}$ W.P. Clifford provided a more hard-headed opinion when he stated, 'the small holding has not been a success. You don't find successful creameries there as a general rule. The most successful district from a dairying point of view is the medium farm. ${ }^{148}$ The views of leading co-operative activists contrasted with those found in the Minority Report, which lamented the lack of focus on the small farmer. As such, the IAOS provided an expert-backed justification for the government to prioritise larger farmers over their smaller counterparts and agricultural labourers.

Co-operative committees could act as important power-brokers in helping to dictate the dissemination of credit in a rural district. Robert Anderson illuminated the procedure by which someone became a member of a co-operative credit society. Committees decided upon eligibility for membership of a society based upon the condition that 'his character is all right ... where the application is rejected the Committee are not under any obligation to state their reasons for 
objection' ${ }^{149}$ This process gave the committees significant discretionary powers to direct a locality's social and economic make-up, which helped to bring about the idea of the larger, more financially reliable farmer as the ideal co-operative subject during a decade of economic challenges.

Still, a renewed co-operative credit sector appeared to provide one means to improve the social stature of small farmers. The parlous state of co-operative credit in the 1920s provided a cause for concern. H.F. Norman contrasted the development of Irish credit societies with the more successful German Raiffeisen credit movement. In Germany, local co-operative infrastructure started with the establishment of a credit society and other types of co-operatives followed. In Ireland, the opposite occurred. Creameries sprang up without reference to a local credit society and therefore bypassed the necessity for a society devoted to the provision of loan capital. ${ }^{150}$ Instead, creamery societies often provided an informal, but unsound, credit function as they frequently paid advances to members in lieu of milk yet to be supplied. These loans often placed societies and their members in financial difficulty. For example, in April 1922 Ardfert Co-operative Society served a writ to the widow of a deceased member in order to retrieve over $£ 175$ due to the society in unpaid cash advances. ${ }^{151}$ Rathmore Co-operative Society suffered as a result of its lax attitude to the supply of credit. An attempt to restart the retail business failed in June 1924. As Nicholas O'Brien reported, the 'Store Department has been closed for the past few weeks owing to the large amount of money outstanding for store goods ... too much credit was given'. ${ }^{152}$

Such occurrences led Fr Finlay to believe that farmers drew too heavily upon the financial resources of societies when they already possessed ample funds in the bank and he suggested 'we require a little tightening of the reins'. ${ }^{153}$ Norman thought that the interest taken in the revitalisation of co-operative credit after independence offered an opportunity for the state to start again: 'I think that the State might do something ... to show its interest in these societies when they regard them as useful, and in general sound institutions'. Part of Norman's purpose in giving evidence to the Commission focused upon the need for the IAOS to perform a regulatory role in any effort to foster a new wave of credit societies. He recommended that he 'would make any encouragement by the State [in establishing credit societies] contingent on the affiliation of the Society to the ... IAOS, because I consider these societies require a good deal of supervision'. ${ }^{154}$

The Agricultural Commission criticised the existent financial position of credit societies, equating the practices of many as 'a negation of the true purpose of co-operation, whereby each member should bear his appropriate share of the responsibility'. Too many societies suffered from under-capitalisation and 'the character and training on the people engaged has been deplorable'. Over-reliance on informal credit provided at the creamery proved detrimental to the inculcation of self-reliance. Three major criticisms emerged from the report. First, members needed to subscribe a higher level of capital to their co-operative societies to end 
reliance upon bank loans. Second, 'a few "strong” men' bore financial responsibility for the society and by implication the community. Finally, societies proved too willing to give credit. ${ }^{155}$ In order to remedy this, the Agricultural Commission decided that co-operative credit societies needed reintroduction. The report criticised the IAOS's long-term concentration upon creameries at the expenses of other sectors and suggested promotional efforts needed to focus elsewhere than upon those societies that contributed 'more liberally than credit banks to the central funds'. The Agricultural Commission recommended that the Irish Government expand the co-operative credit sector with the argument that 'the existence of a number of active and solvent credit banks is evidence of mutual trust, which is the spirit of co-operation'. ${ }^{156}$ Thus began a state co-ordinated attempt to achieve what Robert Anderson described as the 'capitalisation of honesty' ${ }^{157}$

Efforts to revive the co-operative credit sector proved well timed. A memo prepared by the Department of Agriculture in 1925 emphasised the importance of co-operative credit societies to protect farmers from economic ruin. A potentially ruinous outbreak of fluke disease threatened to wipe out Ireland's dairy cattle stocks. The Department's support for the extension of co-operative credit targeted regions most affected.

The Department's Agricultural Credit Scheme operates through the medium of approved Agricultural Credit Societies in districts where farmers have in recent months suffered losses of livestock, mainly as a result of Fluke disease. ${ }^{158}$

The outbreak of fluke, a parasitic worm that attacks cow's livers threatened the livelihoods of many dairy farmers. The need to avert an agricultural crisis confirmed the importance attached to reviving co-operative credit societies to the Department of Agriculture. IAOS organisers devoted themselves to the propagation of a new wave of credit societies.

County Kerry responded well to this drive. In 1922, only Newtownsandes Co-operative Credit Society existed in the county, but even there the society found that life in the early 1920s was incredibly difficult. ${ }^{159}$ However, Newtownsandes Secretary, Edmond Mulvihill, wrote to the Registrar of Friendly Societies in Dublin to explain their unsettled situation during the civil war years as they prepared to apply for the government capitalisation scheme.

I enclose balance sheets for 1921-1922-1923-1924. I am sorry to have delayed them so long. The Society got mixed up in political matters, but things are normal again. The Society are trying to avail of the Government scheme and I will be obliged to you if you send me the 1924 balance sheet as the inspectors may require it. ${ }^{160}$

By 1928, the number of credit societies in County Kerry climbed to fourteen because thirteen fluke societies were organised. In Kerry where the cattle stocks were affected by the fluke outbreak co-operative societies took advantage of 
interest-free loans offered by the Department of Agriculture. For example, Ballymacelligott Co-operative Society established a credit society in 1925 . That June the committee applied for an initial loan of $£ 1,000$ after guaranteeing initial deposits of $£ 1,000$ from members who needed to replenish cattle stocks. ${ }^{161}$ IAOS support of Ballymacelligott Credit Society proved critical. Robert Anderson lobbied the Department of Agriculture on the society's behalf putting forward a case for a government advance. The Department responded by sending Anderson a cheque for $£ 826$, which he forwarded to the secretary of Ballymacelligott Society. ${ }^{162}$ The government matched deposits lodged by members at a ratio of 2:1 to incentivise farmers to place deposits in the new society. ${ }^{163}$ Further loans from the government resulted - $£ 840$ on 23 December 1925 ; $£ 931$ on 1 March 1926; $£ 1,032$ on 24 March 1926; and $£ 1,140$ on 30 March 1926 . $^{164}$

Credit societies sparked a recovery from the fluke epidemic as farmers replenished their herds. Charles Riddall's report for 4 February 1926 showed that Ballymacelligott Co-operative Credit Society counted 111 members, who drew modest amounts from the new bank. The average loan granted was about $£ 40$, while the largest single loan was $£ 50$ pounds. Early enthusiasm was high. By 4 February 1926 local members had deposited a combined total of $£ 1,814$ and received $£ 1,666$ from the Department of Agriculture. An important feature of the government loans related to the fact that no interest was charged for the first three years. The credit society primarily issued loans for the purchase of milk cows to replenish cattle stocks. Riddall visited again a fortnight later and noted that the membership climbed to 153 . He described Ballymacelligott as an area that revolved around the creamery business and observed that 'the people in the locality generally are thrifty and, potentially at least, well off. Riddall detailed with satisfaction that traditional opponents to co-operation derived no benefit from the new society's existence:

No case of a shopkeeper having been admitted to membership or having been granted a loan or of any deposit having been received from a shopkeeper has come under my personal notice in this or any other credit societies in the County Kerry which I have recently visited. ${ }^{165}$

The establishment of the fluke co-operative credit societies shored up the position of local dairy farmers and cemented the successful embedding of a local co-operative infrastructure in north Kerry.

The new co-operative credit societies highlight how committee members accrued local power. Committees used informal discretionary powers to exclude certain local inhabitants from the benefits of membership to the local co-operative. When asked by one committee member about the criteria to be met when admitting members to one of these new societies, Robert Anderson responded: 'The chief consideration to which they should give attention would be the character of the applicant rather than upon the security the society should rely for 
repayment.' The importance of an applicant's character emerged as an important principle when it came to working out who qualified for a loan: 'Every loan must be secured by two persons besides the borrower, but the known good character of the borrower is of far more importance than anything else from the Society's point of view. ${ }^{\text {'166 }}$

What constituted good character remained open to interpretation, but complaints from smaller farmers suggested a connection to social status. One member of the Tralee Co-operative Credit Society complained to the Department of Agriculture that the society's committee rejected his loan application without satisfactory justification. Michael O'Sullivan described himself as 'a small farmer holding over twenty-one acres of good land on which I have only two cows presently ... the farm is capable of carrying eight'. He requested a loan of $£ 50$ to replenish his small herd and described conditions in the rural hinterland around Tralee as one of 'dire distress ... amongst small farmers here'. Despite O'Sullivan's membership of the society the loan application was refused and he accused 'large farmers and cattle dealers [of] drawing the money which I'm sure was intended for the small farmers' ${ }^{167}$ Co-operative committees exerted control over the direction societies by policing the distribution of vital credit resources. Larger farmers with greater potential for development benefited while smaller farmers became marginalised. Committees interpreted what constituted character in terms of an individual's economic position and processed loan applications duly. The emigration of small farmers and labourers remained an important feature of land development in Ireland throughout the twentieth century, with smallholdings consolidated under the ownership of larger farmers. ${ }^{168}$ While in the past Horace Plunkett had promoted co-operatives as one way to stem emigration, by the 1920s the way in which the co-operative credit market operated suggested that financial support that might otherwise keep people on the land proved elusive.

Co-operative credit societies provided the government with an effective instrument to placate an unsettled and vulnerable rural population. Combined efforts between the IAOS and Department of Agriculture resulted in the establishment of 52 new credit societies, while many moribund societies started up once again. By 1931, 114 credit societies worked with only one of the new wave of societies winding up in that time. Most of these new societies were those established during the fluke epidemic. Throughout the 1930s and 1940s the fluke credit societies made no new loans and largely existed to service outstanding debts made to farmers during the outbreak. The second wave of credit societies remained a part of the IAOS movement but maintained a nominal existence only. Like the co-operative credit movement before 1914, new societies remained reliant upon state funding for capitalisation. The government earmarked a sum of $£ 100,000$ to provide initial capital to new credit societies, which received this money in proportion to deposits invested by prospective members. ${ }^{169}$ 
In a period where the legitimacy of the state remained contested, the government gained the support of farmers by directing funding through this revived co-operative credit network. In 1927, the government created a state-sponsored agency, the Agricultural Credit Corporation (ACC) to improve credit provisions for farmers. ${ }^{170}$ The ACC collaborated with the IAOS to co-ordinate the release of loan capital via the national network of co-operative societies. These societies lent to farmers in order to purchase more dairy cows and stimulate levels of butter production. ${ }^{171}$ The ACC had distributed about $£ 1,000,000$ to farmers through the co-operative credit network by $1932 .{ }^{172}$ This body also issued loans to undercapitalised cooperative creameries to purchase new equipment and also helped finance the new midlands creameries. ${ }^{173}$ The creation of the ACC confirmed the enmeshed role of the state and co-operative movement in driving Irish development. Through the instrument of the co-operative society, the government recapitalised depressed rural communities, and demonstrated a commitment to the improvement of Irish agricultural produce - although not all people shared equally in the independence dividend.

\section{Co-operation in the $1930 \mathrm{~s}$}

In 1932, the Irish Government published Saorstát Eireann: Official Handbook to commemorate the tenth anniversary of the foundation of the Irish Free State. The publication's timing coincided with the handover of power from Cumann na nGaedheal to Fianna Fáil. This represented a significant, but tense, political moment for the young state, as it meant the transfer of power from the political party that supported the Treaty to a party made up of Republicans opposed to it. The book offered a defence of the Cumann na nGaedheal administration, arguing that the political, social and economic institutions which underpinned the Free State provided satisfactory evidence that the previous decades of struggle represented a worthwhile price. The main source of the Free State's claim to political success related to its work towards the modernisation of Irish society born out of free political institutions. Bulmer Hobson, a veteran nationalist, edited the book, which offered an opportunity to survey the progress made 'at the end of the first decade of national freedom'. Hobson stated that centuries of conflict between English government and Irish people meant that Cumann na nGaedheal, 'assumed control of a country reduced by war and misgovernment to a state bordering on chaos' and its record needed to be understood in this context. Ireland required 'an immense work of political, legal, social and economic reconstruction'. In the end, Hobson concluded:

Constructive work and development in every direction which, under the old regime, could never have been attempted are now possible, and the energies which for generations were absorbed in the struggle for political autonomy set free for the work of social and economic reconstruction. ${ }^{174}$ 
The book celebrated different aspects of life in the Free State and codified a range of discourses about the character and ideals of Irish life repeated by nationalists and agrarian experts over the course of previous decades. Topics ranged from literature and history to banking and agriculture. Joseph Hanly, an inspector of agricultural science, authored an essay arguing that agriculture formed the historic basis of Ireland's economy and that 'Gaelic Civilization Ireland was entirely rural'. Hanly encapsulated an official view of national development that prevailed by the early 1930s. He cited the abundance of evidence found in Gaelic literature, both 'direct and implied', to show that Ireland possessed a long and successful tradition as an agricultural nation. ${ }^{175}$ Hanly reminded readers that the IAOS pre-dated the Free State and referred to the important role played by the cooperative movement when it undertook the work of advising farmers on agricultural matters as well as co-operation [and] ... carried out a great amount of pioneer work'. The Free State reaped the benefit of this work and the government continued to utilise co-operative societies to improve the quality of agricultural output. In the end, 'agriculture is not only the most important industry of the Irish Free State, but that in view of the valuable resources of the country, each aspect is capable of very great development'. ${ }^{176}$

In an uncompromising book published a year earlier, Hanly went into more detail about his ideal form of the Irish nation-state. In The National Ideal, Hanly envisaged a Gaelic, Catholic state that used co-operative institutions to realise a superior national archetype. On the front cover was an etching by the artist Sean Keating. Keating's illustration echoed a soviet realist style that portrayed an idealised, rural family looking towards a source of light upon which is emblazoned the image of a crucifix, sickle and anvil. Under the image is stated, 'Dia, Tir is Teanga', which translates as 'God, Country and Language' (see figure 6.1). One contemporary reviewer for a Jesuit journal described this frontispiece as 'at once severely spiritual and pointedly practical in its lesson'. ${ }^{177}$

The idea of co-operation as a desirable and normative basis for national behaviour showed how deeply embedded elements of its ideology became within contemporary political discourse. In economic terms, Hanly argued that all forms of activity needed to work in subservience to an idealised form of an Irish nationality, which he equated to 'a supreme form of co-operation'. The Irish past showed how strong English influences promoted an individualistic and selfish conception of development. To counter this effect 'co-operation must be made a gigantic implement for national economic cultivation in Ireland'. ${ }^{178}$ Hanly's conception of an ideal co-operative organisation moved away from Plunkett's professed non-political and non-sectarian version towards one that accentuated the intersections between economics, religion and nationalism. Hanly anticipated a corporatist tendency that emerged in Ireland during the 1930s, which advocated the organisation of socio-economic structures compatible with Catholic social teaching. ${ }^{179}$ As Ireland continued to define its position as an independent nation-state in the 1930s, 


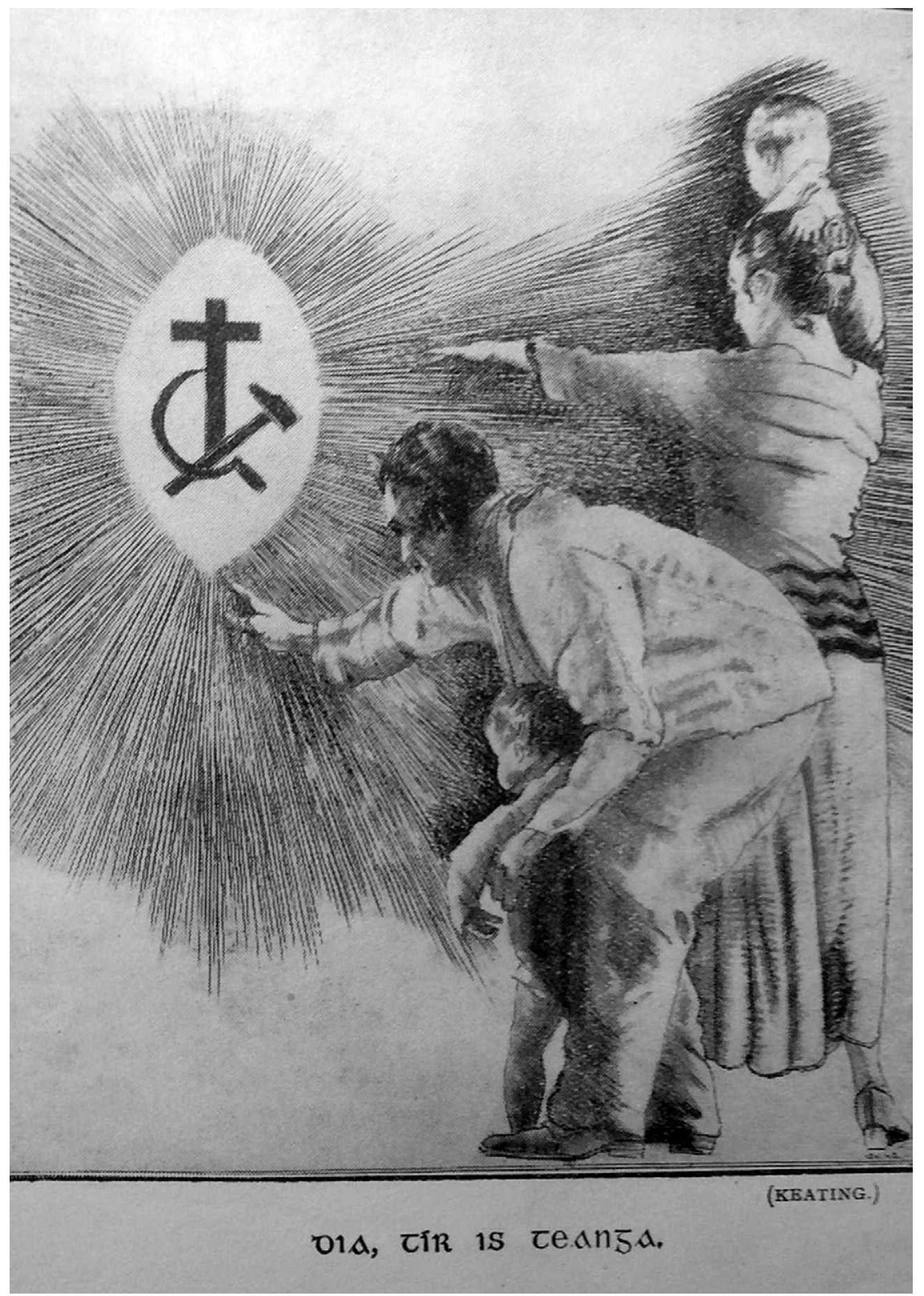

Figure 6.1 Sean Keating's frontispiece to Joseph Hanly's The National Ideal 
co-operation remained a recognisable and familiar paradigm along which future success might derive - albeit one with potential to be incorporated into a Catholicisation of Irish life.

The Irish Free State projected itself as an agricultural country. Nationalists believed that agricultural improvement provided the best means to achieve successful economic development and national prosperity. Intellectuals, policymakers and civil servants made the case for agricultural development as the natural economic policy and the co-operative movement featured in this process. The IAOS used its influence to affect the trajectory of Irish agricultural policy after 1922. Even as the Irish Government adopted a policy of economic protectionism after 1932, the improvement of agricultural production remained a major concern. The economist and co-operative advocate, Joseph Johnston, was no supporter of the new Fianna Fáil Government's chosen trade policy, but conceded that 'the main problem of the Irish economy now is, not the creation of new industries, but the expansion of the home market for the products of our agriculture and of existing industries'. ${ }^{180}$ While a debate about whether to adhere to free trade or to embrace protectionism occurred on an international level, in Ireland the commitment to the intensification of agricultural production remained entrenched as the economic orthodoxy until the 1950 s. $^{181}$

The economic record for Irish agriculture until 1932 was mixed. A global fall in prices at the end of the 1920s affected all Irish farm produce. Disappointing price movements during the 1920s and 1930s meant dairying experienced no spectacular economic return and butter exports dropped from a value of $£ 4.6$ million in 1929 to $£ 3.3$ million in $1930 .{ }^{182}$ Nevertheless, the Irish share of the British market in butter, eggs and cattle remained stable throughout the 1920 s. ${ }^{183}$ The Irish Government passed measures that ensured Irish farmers remained competitive and without the targeted legislation and utilisation of the co-operative infrastructure, the experience could have been more fraught. George O'Brien argued that the Department of Agriculture utilised the maximum potential of agricultural resources and developed pre-existent branches of production within the Free State. The stimulation of food production allayed fears of food scarcity and Patrick Hogan's policies 'ensured that any public money spent on agriculture would be employed productively by being devoted to the building up of the efficiency of the industry. ${ }^{184}$

Patrick Hogan remained Minister for Agriculture until the fall of the Cumann na nGaedheal Government and has been assessed as 'a talented and hard-working minister' who instigated much-needed improvement in the quality of agricultural inputs and outputs. His decision to establish state agencies such as the ACC proved influential interventions. ${ }^{185}$ Yet the effectiveness of these policies required the pre-existence of co-operative societies to facilitate this work. The IAOS and the co-operative movement remained the most dynamic network in Irish agriculture. Co-operative societies utilised the available state assistance to ensure 
they outlived the private creamery sector, but there was a price to pay. After the Wall Street crash the movement relied more heavily on this state support - a far cry from the voluntary movement envisaged by Plunkett, $Æ$ and Finlay. ${ }^{186}$ Co-operative societies embodied the state for much of the rural population. For many rural people, the state revealed itself at the site of the local co-operative. Whether through financial support from credit societies or the everyday business of working through the creamery, a popular understanding of the state and its effect upon the population was understood through the co-operative movement's network.

The 1930s marked the end of an era for the Irish co-operative movement. Horace Plunkett died in Surrey in March 1932, but lived to see the movement he created leave an extraordinary impact upon his home country. Throughout his final years, he remained in touch with the movement he founded as President of the IAOS but his interest shifted to mainstreaming agricultural co-operation across the globe. He organised a conference in July 1924 that gathered delegates from across the British Empire to discuss how agricultural co-operation might be promoted as a solution to problems of underdevelopment elsewhere. He founded the Horace Plunkett Foundation in Oxford to continue the study and promotion of agriculture in rural settings. The uptake of co-operation in other rural countries allowed Plunkett to point to the influence of the policy maxim of 'Better Farming, Better Business, Better Living' as evidence of his 'Irish formula accepted'. ${ }^{187}$

Æ continued as the editor of Irish Statesman until its demise in 1930. Throughout his final years he remained a popular character in Dublin as he nurtured the next generation of literary and artistic talent. When he died in July 1935 his funeral cortège in Dublin extended for over a mile as his remains made their final journey from Plunkett House, where so much of his life was spent, to Mount Jerome cemetery. The funeral revealed the extent of Æ's diverse and popular appeal as the Irish Times reported: 'At his coffinside were bankers, journalists, labour men, leaders of State, poets and artists of international distinction, unknown workers, university professors - mostly representatives of social and economic opposition - all in sympathy by the side of Æ⿸尸's bier. ${ }^{\text {'188 }}$ All came to pay their respects to a man who at some stage offered inspiration, intellectual guidance and support.

By the time the two most famous and committed of Irish co-operators passed, the original idealism that once animated the movement had settled down into the mundane business of rural life. The co-operative societies framed everyday working practices, provided a social space, and showed that an alternative and radical economic model could become an accepted social norm. The co-operative creameries that once proved to be such a point of contention in the structure of rural society graduated into business institutions familiar to families across the countryside. 


\section{Notes}

1 A subsequent Act passed on 6 December 1922 confirmed the Irish Free State's legal status as an autonomous Dominion of the British Empire. D.W. Harkness, The Restless Dominion: The Irish Free State and the British Commonwealth of Nations, 1921-1931 (Dublin: Gill \& Macmillan, 1969), 21-29.

2 'The New Era', Irish Homestead, 17 December 1921, 841-844.

3 'Its Future Work', Irish Homestead, 11 February 1922, 83.

4 IAOS, Annual Report, 1921, 44-48.

5 Basil Chubb, The Government and Politics of Ireland, 3rd edn (London: Longman, 1992), 3-5.

6 Garret Fitzgerald, Reflections on the Irish State (Dublin: Irish Academic Press, 2003), $20-21$.

7 Chubb, The Government, 1-21.

8 Francis MacManus (ed.), The Years of the Great Test, 1926-1939 (Cork: Mercier Press, 1967).

9 Alvin Jackson, Ireland, 1798-1998: Politics and War (Oxford: Blackwell Publishers Ltd, 1999), 258-262; John M. Regan and Mike Cronin, 'Introduction: Ireland and the Politics of Independence, 1922-49: New Perspectives and Re-considerations', in Ireland: The Politics of Independence, 1922-49, ed. by Mike Cronin and John M. Regan (Basingstoke: Macmillan, 2000), 1-12 (p. 2).

10 Clifford Geertz, The Interpretation of Cultures: Selected Essays (New York: Basic Books, 1973), 234-5.

11 Akhil Gupta, 'Blurred Boundaries: The Discourse of Corruption, the Culture of Politics and the Imagined State', American Ethnologist, 22.2 (1995), 375-402 (pp. 376-378).

12 Mícheál Ó Fathartaigh, Irish Agriculture Nationalised: the Dairy Disposal Company and the Making of the Modern Irish Dairy Industry (Dublin: Institute of Public Administration).

13 IAOS, Annual Report, 1923, 14.

14 Ciara Meehan, The Cosgrave Party A History of Cumann na nGaedheal, 1923-33 (Dublin: Royal Irish Academy, 2010).

15 John M. Regan, The Irish Counter-Revolution, 1921-1936: Treatyite Politics and Settlement in Independent Ireland (Dublin: Gill \& Macmillan, 1999).

16 On these efforts see Michael Kennedy and Joseph Skelly (eds), Irish Foreign Policy, 1919-1966: From Independence to Internationalism (Dublin: Four Courts, 2000).

17 Paul Murray, The Irish Boundary Commission and its Origins, 1886-1925 (Dublin: University College Dublin Press, 2011).

18 Donal Corcoran, 'Public Policy in an Emerging State: The Irish Free State, 1922-25', Irish Journal of Public Policy, 1 (2009), http://publish.ucc.ie/ijpp/2009/01/corcoran/05/ en [accessed 19 August 2013].

19 J.J. Lee, Ireland, 1912-1985: Politics and Society (Cambridge: Cambridge University Press, 1989), 69-71.

20 IAOS, Annual Report, 1923, 7.

21 Mary E. Daly, Industrial Development and Irish National Identity, 1922-39 (Dublin: Gill \& Macmillan, 1992), 16. 
22 Saorstát Éireann, Agricultural Statistics, 1847-1926: Reports and Tables (Dublin: Stationery Office, 1928), lxv.

23 Daly, Industrial Development, 15.

24 Evidence of T.P. Gill to Commission on Agriculture, 16, 17 and 18 January 1923, NAI AGF/2005/68/80.

25 Kieran A. Kennedy, Thomas Giblin and Deirdre McHugh, The Economic Development of Ireland in the Twentieth Century (London: Routledge, 1988), 37.

26 Donal Corcoran, Freedom to Achieve Freedom: The Irish Free State, 1922-1932 (Dublin: Gill \& Macmillan, 2013), 153.

27 Eunan O'Halpin, 'Politics and the State, 1922-1932', A New History of Ireland, Volume VII: Ireland 1921-1984, ed. by J.R. Hill (Oxford: Oxford University Press, 2003), 86-126 (p. 113).

28 George O’Brien, 'Patrick Hogan: Minister for Agriculture, 1922-1932', Studies, 25.99 (1936), 353-368 (p. 360).

29 Cormac Ó Gráda, A Rocky Road: The Irish Economy Since the 1920s (Manchester: Manchester University Press, 1997), 145.

30 Cormac Ó Gráda, Ireland Before and After the Famine: Explorations in Economic History, 1800-1925 (Manchester: Manchester University Press, 1988), 172. This contrasts with James Meenan who argued that voluntary organisations were irretrievably weakened by independence. Meenan, The Irish Economy Since 1922 (Liverpool: Liverpool University Press, 1970), 34-35.

31 O'Halpin, 'Politics and the State', 115.

32 Joseph Johnston, 'Free Trade or Protection for Irish Industries?' Irish Economist, 8.1 (1923), 54-65 (pp. 64-65).

33 Ronan Fanning, The Irish Department of Finance, 1922-1958 (Dublin: Institute of Public Administration, 1978), 202-206; Lee, Ireland, 118-120.

34 Ó Gráda, A Rocky Road, 46; Lee, Ireland, 1912-1985, 108.

35 Patrick Hogan to the Post-Master General, 22 May 1922, NAI FIN/1/3086.

36 James Gordon to Captain Petherick, 8 March 1922, PRONI, FIN/18/2/332.

37 IAOS, Annual Report, 1923, 6.

38 IAOS, Annual Report, 1922, 9; IAOS, Annual Report, 1924, 6.

39 Desmond A Gillmor, 'Land and People, c.1926', in A New History of Ireland, Volume VII: Ireland, 1921-84, ed. by J.R. Hill (Oxford: Oxford University Press, 2003), 62-85 (p. 70).

40 Michael Hopkinson, Green Against Green: The Irish Civil War (Dublin: Gill \& Macmillan, 1988), 115-122.

41 Bill Kissane, The Politics of the Irish Civil War (Oxford: Oxford University Press, 2005), 1.

42 Kissane, Politics of the Irish Civil War, 4; Peter Hart, The IRA at War, 1916-1923 (Oxford: Oxford University Press, 2003), 41.

43 Anne Dolan, Commemorating the Irish Civil War: History and Memory, 1923-2000 (Cambridge: Cambridge University Press, 2003).

44 Hopkinson, Green Against Green, 273.

45 Michael Hopkinson, 'Civil War and Aftermath, 1922-4', A New History of Ireland: 1921-1984, ed. by J.R. Hill (Oxford: Oxford University Press, 2003), 31-61 (p. 54). 
46 Trevor West, Horace Plunkett, Co-operation and Politics (Gerrards Cross, Bucks.: Colin Smythe, 1986), 197-216.

47 'Fate of the Irish Laodiceans', Irish Homestead, 3 February 1923, 61-62.

48 Henry Summerfield, That Myriad-Minded Man: A Biography of George William Russell 'AE' 1867-1935 (Gerrards Cross, Bucks.: Colin Smythe, 1975), 218-227; Nicholas Allen, Modernism, Ireland and Civil War (Cambridge: Cambridge University Press, 2009), 36.

49 James J. Kennelly, 'Normal Courage: R.A. Anderson and the Irish Co-operative Movement', Studies, 100 (2011), 319-330.

50 Ó Fathartaigh, Irish Agriculture Nationalised, 16.

51 Meenan, The Irish Economy, 35.

52 Donal O'Sullivan, The Irish Free State and its Senate: A Study in Contemporary Politics (London: Faber \& Faber, 1940), 99.

53 Gavin Foster, 'In the Shadow of the Split: Writing the Irish Civil War', Field Day Review, 2 (2006), 294-303 (pp. 295-296). For more on the Civil War in Kerry see Tom Doyle, The Civil War in Kerry (Cork: Mercier Press, 2008).

54 N.W. O’Brien to R.A. Anderson, 1 October 1922, NAI 1088/800/3.

55 N.W. O’Brien's Report, 6 October 1922, NAI 1088/2/4.

56 N.W. O’Brien to R.A. Anderson, 17 October 1922, NAI 1088/751/8.

57 N.W. O’Brien's Report on Rathmore, 2 December 1922, NAI 1088/798/4.

58 N.W. O’Brien's Report on Rathmore, 20 December 1922, NAI 1088/798/4.

59 'Irregular' was the pejorative term used for Republicans opposed to the Treaty.

60 Thomas de Lacy to R.A. Anderson, 15 and 16 January 1923, NAI 1088/798/4.

61 R.A. Anderson to Thomas de Lacy, 19 January 1923, NAI 1088/798/4.

62 Denis Gwynn, The Irish Free State, 1922-1927 (London: Macmillan and Co., 1928), 285.

63 Corcoran, 'Public Policy'.

64 Commission of Inquiry into the Resources and Industries of Ireland, Report on Dairying and the Dairy Industry, March, 1922 (Dublin: Commission of Inquiry into the Resources and Industries of Ireland, 1922), 1.

65 Roy H.W. Johnston, Century of Endeavour: A Biographical and Autobiographical View of the Twentieth Century in Ireland (Dublin: The Lilliput Press, 2006), 40.

66 James Meenan, George O’Brien: A Biographical Memoir (Dublin: Gill \& Macmillan, 1980), 127.

67 Preface to the Report of the Agricultural Commission, NAI AGF/2005/68/401.

68 'The Agricultural Commission', Irish Homestead, 28 October 1922, 629-630.

69 Evidence of W.P. Clifford to Agricultural Commission, 9 March 1923, NAI AGF/2005/68/35. Also see Martin Maguire, The Civil Service and the Revolution in Ireland: 'Shaking the Blood-Stained Hand of Mr Collins' (Manchester: Manchester University Press, 2008).

70 Report of the Agricultural Commission, 2, NAI AGF/2005/68/401.

71 Report of the Agricultural Commission, 11, NAI AGF/2005/68/401.

72 Report of the Agricultural Commission, 89-102, NAI AGF/2005/68/401.

73 Report of the Agricultural Commission, 9, NAI AGF/2005/68/401.

74 Report of the Agricultural Commission, 66, NAI AGF/2005/68/401. 
75 Report of the Agricultural Commission, 41, NAI AGF/2005/68/401.

76 Report of the Agricultural Commission, 46, NAI AGF/2005/68/401.

77 Report of the Agricultural Commission, 46, NAI AGF/2005/68/401.

78 R.A. Anderson's evidence to Agricultural Commission, 13 December 1923, NAI AGF/2005/68/6.

79 Commission of Inquiry, Report on Dairying, 14-15.

80 T.W. Freeman, Ireland: Its Physical, Historical, Social and Economic Geography (London: Methuen and Co., Ltd, 1950), 202-204.

81 Saorstát Éireann, Agricultural Statistics, xxii.

82 IAOS, Annual Report, 1921, 39.

83 Report of the Agricultural Commission, 46, NAI AGF/2005/68/401.

84 Gwynn, The Irish Free State, 260-261.

85 IAOS, Annual Report, 1931, 5.

86 Confidential Report, Reorganisation of the IAOS, Internal Minute, Department of Agriculture, undated [1926], NAI AGF/2005/82/1497.

87 IAOS, Annual Report, 1924, 31-32.

88 Proposed Re-organisation Scheme of IAOS, 1924-1928, 31 October 1927; B. McAuliffe's Report of Meeting to Dr Smith, Department of Agriculture, 31 October 1927, NAI AGF/2005/82/1495.

89 Saorstát Éireann, Dairy Produce Act, 1924, www.irishstatutebook.ie/eli/1924/act/58/ enacted/en/print.html [accessed 2 October 2017].

90 Dairy Disposal Company Ltd; Re Inspection and Registration of Tubrid Creamery, Ardfert, County Kerry, under Dairy Produce Act 1924, 30 October 1925-5 March 1930, NAI AGF/92/3/655.

91 Thomas de Lacy, Rathmore, to James Fant, 23 February 1928, NAI 1088/798/6.

92 Thomas de Lacy, Rathmore, to James Fant, 21 March 1928, NAI 1088/798/6.

93 R.A. Anderson, With Horace Plunkett in Ireland (London: Macmillan and Co., 1935), 236-237.

94 Conference with Dairy Produce Inspectors, 29 September-2 October 1925, NAI AGF/92/3/570.

95 Ó Fathartaigh, Irish Agriculture Nationalised, 3.

96 IAOS, Annual Report, 1907, 55-56.

97 Evidence of Denis Hegarty, Secretary of the Irish Creamery Manager's Association to the Agricultural Commission, 8 March 1923, NAI AGF/2005/68/95.

98 Evidence of Denis Hegarty, 19 April 1923, NAI AGF/2005/68/95.

99 Report of the Agricultural Commission, 43-44, NAI AGF/2005/68/401.

100 Report of the Agricultural Commission, 42, NAI AGF/2005/68/401.

101 Saorstát Éireann, Agricultural Statistics, xx-xxi.

102 Thomas de Lacy, Rathmore, to R.A. Anderson, Dublin, 29 September 1923; Anderson to Secretary, Department of Agriculture, 2 October 1923, NAI 1088/798/5.

103 James Fant's handwritten note on N.W. O'Brien's Report, 8 July 1924, NAI $1088 / 798 / 5$.

104 John O'Donovan, 'State Enterprises', Journal of the Statistical and Social Inquiry Society of Ireland, 8.3 (1950), 327-348 (p. 330).

105 Ó Fathartaigh, Irish Agriculture Nationalised, 16-17. 
106 Thomas de Lacy, Rathmore, to Henry Kennedy, IAOS, 15 December 1927, NAI 1088/798/6.

107 Department of Agriculture of Saorstát Éireann, Saorstát Eireann, Agriculture: A Note on Some Outstanding Features of the Irish Free State's Agricultural Resources (Dublin: Department of Agriculture, Saorstát Éireann, 1928), 23-24.

108 Mary E. Daly, The First Department: A History of the Department of Agriculture (Dublin: Institute of Public Administration, 2002), 128-133.

109 Saorstát Éireann, Creamery Act, 1928, www.irishstatutebook.ie/1928/en/act/pub/0026/ print.html (Section 13) [accessed 13 September 2012].

110 Saorstát Éireann, Creamery Act, 1928 (Section 10).

111 R.F. Foster, Modern Ireland, 1600-1972 (London: Penguin, 1989), 426.

112 Teddy Fennelly, A Triumph Over Adversity: The History of Donaghmore Co-operative Creamery Ltd, Founded in 1927 (Portlaoise: Arderin Publishing Company, 2003).

113 'New Creameries in Free State', Weekly Irish Times, 25 May 1929, 19.

114 IAOS, Annual Report, 1931, 14-15.

115 Cormac Ó Gráda, Ireland: A New Economic History, 1780-1939 (Oxford: Clarendon Press, 1995), 389-390.

116 G.A. Fleming, 'Agricultural Support Policies in a Small Open Economy: New Zealand in the 1920s', Economic History Review, 52.2 (1999), 334-354.

117 Report of the Agricultural Commission, 26, NAI AGF/2005/68/401.

118 Meenan, The Irish Economy, 35.

119 Report of the Agricultural Commission, 20, NAI AGF/2005/68/401.

120 Ó Gráda, Ireland, 261.

121 Report of the Agricultural Commission, 20, NAI AGF/2005/68/401.

122 IAOS, Annual Report, 1910, 89-90.

123 IAOS, Annual Report, 1914, 10.

124 Evidence of Denis Hegarty, NAI AGF/2005/68/95.

125 Evidence of W.P. Clifford, NAI AGF/2005/68/35.

126 Report of the Agricultural Commission, 104, NAI AGF/2005/68/401.

127 William O'Connell, Rattoo, to R.A. Anderson, 19 May 1924, NAI 1088/800/3.

128 Irish Associated Creameries Limited, Report of the Committee to the Members for the Year ended December 31st, 1928 (Dublin: Browne and Nolan, n.d.), 2-4.

129 C.C. Riddall, IAOS, Dublin to Denis Hegarty, Irish Associated Creameries, Dublin, 22 July 1927, NAI 1088/800/3.

130 Thomas de Lacy to Henry Kennedy, 22 March 1927, NAI 1088/798/5.

131 Department of Agriculture, Saorstát Éireann, 24.

132 Ó Fathartaigh, Irish Agriculture Nationalised, 84.

133 IAC, Report ... 1928, 2.

134 Jerry O’Connor, Rattoo to Henry Kennedy, Dublin 7 September 1928, NAI 1088/800/3.

135 N.W. O’Brien to Henry Kennedy, 15 September 1928, NAI 1088/800/3.

136 N.W. O’Brien to Henry Kennedy, 22 September 1928, NAI 1088/800/3.

137 Daly, The First Department, 140.

138 'The Future of the IAC', IAC Bulletin, 1.12 (September 1930), 1-3 (p. 2).

139 Ó Fathartaigh, Irish Agriculture Nationalised, 84. 
140 Report of the Agricultural Commission, 3, NAI AGF/2005/68/401.

141 IAOS, Annual Report, 1922, 17.

142 Evidence of H.F. Norman to Agricultural Commission, 23 May 1923, NAI AGF/2005/68/164.

143 Rules of the Valentia Island Agricultural Bank (Dublin: Irish Agricultural Wholesale Society, n.d.), 3, NAI RFS/SA/374/A, Valentia Island Agricultural Bank, Kerry.

144 Evidence of H.F. Norman, 23 May 1923, NAI AGF/2005/68/164.

145 Evidence of H.F. Norman, NAI AGF/2005/68/164.

146 Horace Plunkett, Ireland in the New Century: with an Epilogue in Answer to Some Critics (London: John Murray, 1905), 210.

147 Evidence of Rev T.A. Finlay, NAI AGF/2005/68/58.

148 Evidence of W.P. Clifford, NAI AGF/2005/68/35.

149 Evidence of R.A. Anderson, NAI AGF/2005/68/6.

150 Evidence of H.F. Norman, NAI AGF/2005/68/164.

151 Ardfert Society v Jane Dowling, 11 April 1922, KLHA, O’Connell Papers.

152 N.W. O’Brien, Report of Visit, 14 June 1924, NAI 1088/798/5.

153 Evidence of Rev. T.A. Finlay, NAI/AGF/2005/68/58.

154 Evidence of H.F. Norman, NAI/AGF/2005/68/164.

155 Report of the Agricultural Commission, 42-43, NAI/AGF/2005/68/401.

156 Report of the Agricultural Commission, 44, NAI AGF/2005/86/401.

157 Anderson, With Horace Plunkett, 251.

158 C.C. Riddall and H.F. Norman Correspondence to Department of Agriculture, re Memo, 'Agricultural Credit', 5 August 1925, NAI AGF/92/3/879.

159 Newtownsandes Co-operative Credit Society Correspondence File, NAI/1088/751/3.

160 Edmond Mulivihill to O'Connor Miley, 1 July 1925, NAI RFS/SA/403/B.

161 John Byrne, Ballymacelligott to Dr Smith, Secretary, Department of Agriculture, June 1925, NAI 1088/70/2.

162 R.A. Anderson to Dr Smith, 9 December 1925; Smith to Anderson, 12 December 1925, NAI 1088/70/2.

163 Department of Agriculture Memo, 'Agricultural Credit', 5 August 1925, NAI 92/3/879.

164 Dr Smith to R.A. Anderson, 23 December 1925, 1, 24 and 30 March, 1926, NAI $1088 / 70 / 2$.

165 C.C. Riddall, Reports on Ballymacelligott Co-operative Credit Society, 4, 17 and 18 February 1926, NAI 1088/70/2.

166 R.A. Anderson to John Byrne, 7 September 1925, NAI 1088/70/2.

167 Dr Smith to H.F. Norman, 7 December 1925, NAI 1088/70/2.

168 Robert E. Kennedy, The Irish: Emigration, Marriage and Fertility (London: University of California Press, 1973), 207-208.

169 IAOS, Annual Report, 1931, 16.

170 Ó Gráda, A Rocky Road, 145.

171 Anderson, With Horace Plunkett, 260-261.

172 J.P. Colbert, 'The Banking and Currency System', in Bulmer Hobson (ed.), Saorstát Éreann: Official Handbook (Dublin: Talbot Press, 1932), 97-108 (p. 103); Daly, The First Department, 137.

173 IAOS, Annual Report, 1931, 16; Patrick Bolger, The Irish Co-operative Movement: Its History and Development (Dublin: Institute of Public Administration, 1877), 179. 
174 Bulmer Hobson, 'Introduction', Saorstat Eireann: Official Handbook (Dublin: Talbot Press, 1932), 15-16.

175 Joseph Hanly, 'Agriculture', Saorstat Eireann: Official Handbook (Dublin: Talbot Press, 1932), 115-127 (p. 115).

176 Hanly, 'Agriculture', 125-127.

177 T.C., 'Review of “The National Ideal”', Studies, 21.83 (1932) 499-500 (p. 500).

178 Joseph Hanly, The National Ideal: A Practical Exposition of True Nationality Appertaining to Ireland (Dublin: Dollard Printinghouse, 1931), 270-271.

179 Brian Girvin, 'The Republicanisation of Irish Society, 1932-48', A New History of Ireland, Volume VII: Ireland 1921-1984, ed. by J.R. Hill (Oxford: Oxford University Press, 2003), 127-160 (p. 153); Michel Peillon, 'Interest Groups and the State in the Republic of Ireland', Irish Society: Sociological Perspectives, ed. by Patrick Clancy, Sheelagh Drudy, Kathleen Lynch and Liam O'Dowd (Dublin: Institute of Public Administration, 1995), 358-378 (pp. 368-370).

180 Joseph Johnston, The Nemesis of Economic Nationalism and Other Lectures in Applied Economics (London: P.S. King and Son Ltd, 1934), 94.

181 Tom Garvin, Preventing the Future: Why Was Ireland So Poor For So Long? (Dublin: Gill \& Macmillan, 2004), 145.

182 Lee, Ireland, 113-115.

183 Daly, The First Department, 141.

184 O’Brien, 'Patrick Hogan', 360-361.

185 Ó Gráda, A Rocky Road, 144-145.

186 IAOS, Annual Report, 1934, 7.

187 Horace Plunkett Foundation, Agricultural Co-operation: in its Application to the Industry, the Business, and the Life of the Farmer in the British Empire (London: George Routledge and Sons, 1925), 4.

188 A Friend, 'The Home-coming of Æ', Irish Times, 22 July 1935, 6. 